\title{
Using Patent Development, Education Policy AND RESEARCH AND DEVELOPMENT EXPENDITURE Policy to Understand Differences Between Countries - The Case of Estonia and Germany
}

\section{Pawan Kumar Dutt; Mike Wahl and Tanel Kerikmae}

TalTech Law School of Tallinn University of Technology pawan.dutt@taltech.ee; mike.wahl@ebs.ee; tanel.kerikmae@taltech.ee DUTT, Pawan Kumar; WAHL, Mike; KERIKMAE, Tanel. Using Patent Development, Education Policy and Research and Development Expenditure Policy to Understand Differences Between Countries - The Case of Estonia and Germany. International and Comparative Law Review, 2019, vol. 19, no. 1, pp. 190233. DOI: 10.2478 /iclr-2019-0007

\begin{abstract}
Summary: Innovation is the key factor for economic growth. RDI policies pursued in a wholesome manner can have long term social significance. The true value of an invention depends upon factors such as its economic value, strategic value, cultural value and social value. Estonia and Germany share a long historical and legal connection. The German economy is strong and Germany has safeguarded it's manufacturing, mining and construction sector through incremental innovation and focused state funding for RDI activities. Germany runs cost efficient entrepreneurship promotion programs. RDI in Estonia is dependent upon EU funding. Estonia lags behind Germany in respect of several global rankings related to technology and innovativeness. To make the Estonian economy knowledge-driven and technologically intensive, the state must focus on cultural, economic, social and strategic factors. Estonia should adopt RDI policies similar to Germany and also use the new UP regime to help its SMEs to acquire foreign patents.
\end{abstract}

Keywords: RDI, Unitary Patents, State Aid, Intellectual Property and Competition Law, Social System theory, 4S Framework.

\section{Introduction}

In order to be inventive and innovative, societies need to reward their inventors and innovators. One of the tried and tested ways to reward inventors and innovators is to develop effective mechanisms to safeguard intellectual property rights (IPR). Although it may seem that the IPR system is ineffective or inefficient with regard to certain types of modern technologies, the authors believe that the IPR system still works. In support of this assumption, one can point at recent data from the European Patent Office (EPO) which shows that the number 
of patent applications in respect of 4 th Industrial Revolution related inventions (Artificial Intelligence, blockchain technology, etc) are growing worldwide. ${ }^{1}$

Innovation is recognised as the key factor for economic growth. Hence the Lisbon Agenda established the goal of making European Union's (EU) economy competitive and knowledge based. RDI was given great emphasis in the Europe 2020 strategy. It provides for key incentives for RDI at the regional level since transmission of gained knowledge primarily occurs there. ${ }^{2}$

The process of efficiently using effective IPR mechanisms to safeguard new inventions and innovations and to reward their inventors requires a good understanding of the relationship between Research, Development and Innovation (RDI), IPR (especially patents) and productivity. There are wide ranging differences (both fundamentally and structurally) in the economies of different (EU) Member States and these impact national attitudes towards foreign trade, inflation, RDI spending, etc. The economies of the five largest EU Member States stood at $66.8 \%$ of the EU's Gross Domestic Product (GDP). ${ }^{3}$ This disproportionate economic difference can explain why there exist huge technological gaps among developed and developing industrialised nations. The right mix of science and innovation policies can help a society to sustain long term economic growth. ${ }^{4}$

Generally speaking, research studies have shown that propensity towards patents is higher in countries with high GDP levels. This is an indirect confirmation of the link between growth and RDI. Since countries in Eastern Europe, along with Portugal, Italy, Ireland, Greece and Spain display a lower patenting propensity than those in the Western or Northern parts of Europe, it is fair to state that strong political measures are required with regard to local RDI policies, if the abovementioned distance between different European countries and regions is to be reduced. Interestingly, in Germany, Britain and Switzerland, RDI activity is noticed in all regions (being a testament to the culture of innovation being highly prevalent throughout the country) unlike in the case of France and Italy where RDI activities are mostly concentrated in specific regions. ${ }^{5}$

1 European Patent Office. Patents and the Fourth Industrial Revolution. [online]. Available at: http://documents.epo.org/projects/babylon/eponet.nsf/0/17FDB5538E87B4B9C12581 EF0045762F/\$FILE/fourth_industrial_revolution_2017_en.pdf Accessed: 14.06.2019

2 SANSO-NAVARRO, Marcos, VERA-CABELLO María. The long-run relationship between R\&D and regional knowledge: the case of France, Germany, Italy and Spain. Regional Studies, 2018, 52:5, pp 619-631 at 620.

3 Eurostat. National accounts and GDP. [online]. Available at: https://ec.europa.eu/eurostat/ statistics-explained/index.php/National_accounts_and_GDP\#Developments_in_GDP_ in_the_EU:_growth_since_2013 Accessed: 14.06.2019

4 FLORIO, Massimo, FORTE, Stefano, PANCOTTI, Chiara, SIRTORI, Emanuela, VIGNETTI, Silvia. Exploring Cost Benefit Analysis of Research, Development and Innovation Infrastructures: An Evaluation Framework. [online]. Available at: https://arxiv.org/ftp/arxiv/ papers/1603/1603.03654.pdf; Accessed: 14.06.2019

5 COZZA, Claudio, SCHETTINO, Francesco. Explaining the Patenting Propensity: 
Further, it should be taken into account that many European countries in the eastern parts of Europe commenced changes in their IPR structures and policies in the 1990s after the collapse of the USSR. These widespread changes to IP laws and RDI policies stabilised only in the early 2000 s. $^{6}$

In order to be successful, the innovation policies of a nation should identify technology gaps in areas which show the most promise. These gaps can then be suitably amended or filled through public funding in order to positively impact inefficiencies which have crept into the potential market. In this process, it should not be forgotten that the policies need to be broadly diverse so that society develops technologically in a wholesome manner. Official patent data is inherently advantageous for the purpose of studying trends in innovation as they contain a lot of information regarding inventions, their technical fields, geographic locations of those involved in the patenting process, etc. Due to the international efforts of the World Intellectual Property Organisation (WIPO) and other like minded organisations, patent systems globally are now uniform in nature. Further patents of competing industries in different parts of the world can be measured, studied and compared. However, the disadvantage of using patent data for such studies is that some newer technologies concerning software, biotechnology, nanotechnology and others are difficult to patent in different parts of the world. Sometimes, patenting strategies for technologies with short life cycles are perceived from a strategic viewpoint. This often results in a situation where it is more favourable to maintain trade secrets or lead times instead of indulging in actual patenting. Furthermore, several patents can cover single or multiple inventions which results in complicated patent trees which cover different technological aspects. ${ }^{7}$ Hence, one must not forget that an invention can be protected through the use of different forms of IPRs (e.g., patents, trade secrets, copyright, designs, etc.) or without IPR sometimes. Different industrial sectors also very often tend to see the use of IPRs differently. ${ }^{8}$

Patents (especially when weighted in the context of an appropriate quality index) are useful as measuring tools for the purposes of gauging innovation. Nonetheless, patents only represent a mere fraction of the total new knowledge which has been acquired, as they ignore processes or organizational activities in the field of innovation. ${ }^{9}$

A Regional Analysis Using EPO-OECD Data. [online]. Available at: https://mpra.ub.unimuenchen.de/45084/ Accessed: 14.06.2019 at pg. 4

6 Ibid at pg. 8

7 DUTT, Pawan, FERRARO, Simona, CHOCHIA, Archil, MULJAR, Ramona. Using Patent Development, Education Policy and Research and Development Expenditure Policy to Understand Differences between Countries: The Case of Estonia and Finland. Baltic Journal of European Studies, 2018, 8(1), pp. 123-153 at 124.

8 BASBERG, Bjørn. Patents and the measurement of technological change: a survey of the literature. Research Policy, 1987, 16 (2-4), pp. 131-141 at 132.

9 SANSO-NAVARRO, Marcos, VERA-CABELLO María. The long-run relationship between R\&D and regional knowledge: the case of France, Germany, Italy and Spain. Regional Stud- 
RDI tends to be multifaceted and therefore involves many groups (both directly and indirectly) such as businesses, researchers, young professionals, students and the targeted population. RDI projects can cover a vast spectrum of innovation related processes. Knowledge is created and transferred resulting in commercialisation of the researched results. This can have a deep impact on industrial competitiveness on a vast economic scale crossing regional and sometimes national boundaries. At the base of the knowledge-creating processes are always knowledge assets - firm specific resources that are indispensable to create values for the firm. ${ }^{10}$. Transfer of knowledge is understood as moving of knowledge from lower to higher agency levels in explicit or tacit form ${ }^{11}$, also as the domain specific knowledge transferred across the syntactic boundary. ${ }^{12}$ Taking a pragmatic view of knowledge and boundaries Carlile suggests three progressively complex boundaries of knowledge in innovation processes: a) syntactic, b) semantic, and c) pragmatic boundaries and ways of crossing these boundaries correspondingly are knowledge transfer, transition (translation) and transformation. Transforming is creating common interests to share and assess knowledge, when different interests arise, developing an adequate common knowledge (e.g. ownership strategy) is a political process of negotiating interests, making trade-offs between actors, and defining common interests. ${ }^{13}$

A model of knowledge transfer across national boundaries states, that the inputs are owners cross national personal constructs, in the form of cognitive, affective, and biological events. Environmental constructs are representing the environment, and behavioural constructs are representing the behaviour. Inputs are followed by the process of knowledge transfer itself, and finally resulting in the output measured by performance, in form of personal-, social-, political-, and economic values. ${ }^{14}$ When trying to explain why individuals behave as they do, people often refer to attitudes, beliefs, traits, or norms. Values vary in importance as guiding principles in life. Values are one important, especially central component of our self and personality, distinct from attitudes, beliefs, norms, and traits. Values are critical motivators of behaviours and attitudes. ${ }^{15}$

ies, 2018, 52:5, pp 619-631 at 629.

10 NONAKA, Ikujiro, TOYAMA, Ryoko, KONNO, Noboru. SECI, $B a$ and Leadership: a Unified Model of Dynamic Knowledge Creation. Long Range Planning, 2000, vol. 33(1), pp. $5-34$.

11 GUNNAR, Hedlund. A Model of Knowledge Management and the N-Form Corporation. Strategic Management Journal, 1994, vol 15 (S2), pp. 73-90.

12 CARLILE, Paul. Transferring, Translating and Transforming: An Integrative Framework for Managing Knowledge Across Boundaries. Organization Sciences, 2004, vol. 15(5), pp. $555-568$.

13 Ibid and CARLILE, Paul. A Pragmatic View of Knowledge and Boundaries. Organization Science, 2002, 13(4), pp. 442-455.

14 BANERJEE, Supriya, WAHL, Mike, PANIGRAHI, Jayant. Technology, innovation and knowledge transfer: A value chain perspective. International Journal of Mechanical Engineering and Technology (IJMET), 2018, vol. 9 (1), pp. 1145-1161.

15 SCHWARTZ, Shalom. An Overview of the Schwartz Theory of Basic Values. Online Read- 
If RDI policies and consequent development of IPR are pursued in a wholesome manner then they can have great and long term social significance as they create new scientific knowledge, benefit consumers and enhance RDI related cooperation between educational and business institutions thereby creating newer or more jobs and improving global competitiveness rankings. Focused RDI inputs help to attract investors and companies to newly created clusters and science parks, enabling specialisations in specific sectors by allowing for new training methods thereby creating skilled manpower. ${ }^{16}$

The goal of this series of papers is to study how RDI output in certain EU member states can be interpreted using data concerning international patents filed by local enterprises. The intention is to draw a correlation between factors such as patent development, education policy and research and development expenditure policy in order to understand how technological competitiveness of smaller countries can be increased. Estonia is the focal country in all these studies. In previous papers, Estonia has been compared at the OECD level ${ }^{17}$ and with Finland. ${ }^{18}$ In this paper, Estonia is compared with Germany so as to determine what are the best practices which can be availed of by Estonia in the field of RDI related activities? Appropriate government policies are sought to be devised which would help SMEs in Estonia to acquire international patent portfolios.

After the above mentioned introduction, the theoretical background is studied in the light of the $4 \mathrm{~S}$ framework inspired by the social systems theory. The implications of the $4 \mathrm{~S}$ framework towards RDI policies are explored. The German patent and education systems along with German RDI policies are dissected before commencing with a brief comparison of Estonia with Germany. State Aid to support RDI in the context of the new Unitary Patent (UP) regime is analysed. This paper is rounded off by making suitable recommendations for Estonian policy makers, in the light of the above analysis.

ings in Psychology and Culture, 2012, 2(1).

16 European Commission. Guide to Cost-Benefit Analysis of Investment Projects Economic appraisal tool for Cohesion Policy 2014-2020. [online]. Available at: https://ec.europa.eu/ regional_policy/sources/docgener/studies/pdf/cba_guide.pdf Accessed: 14.06.2019 at pg. 278 , table 7.4

17 FERRARO, Simona, DUTT, Pawan, KERIKMAE, Tanel. Using Patent Development, Education Policy and Research and Development Expenditure Policy to Increase Technological Competitiveness of Small European Union Member States. Croatian International Relations Review, 2017, 23(78), pp. 97-126.

18 DUTT, Pawan, FERRARO, Simona, CHOCHIA, Archil, MULJAR, Ramona. Using Patent Development, Education Policy and Research and Development Expenditure Policy to Understand Differences between Countries: The Case of Estonia and Finland. Baltic Journal of European Studies, 2018, 8(1), pp. 123-153. 


\section{Theory}

It is not easy to explain the dynamics of knowledge intensive entrepreneurship or how they thrive in and benefit society. Such entrepreneurship arises because of high technological changes in newly developed fields which bring about strategic changes (newer products, changing actors in the markets, changes in market structures and changes in the rules of the game) both locally and globally in the industry. Consequently entrepreneurs are compelled to reaquaint themselves with ways to handle interactions within these dynamic networks. Due to the multi-disciplinarity of the rapidly evolving technological innovations and the need to specialise, a consequent result is the creation of heterogenous networks of different sized firms, universities, Research and Development (R\&D) organisations, etc. ${ }^{19}$ However, managing of R\&D is highly complicated due to various complicating factors such as globalisation, mass customisation, short technology life cycles, development of new high tech fields such as information and communication technologies (ICT), biotechnology, etc. When it comes to assessing strategic flexibilities of a firm, one needs to discuss the fine balance between cutting costs and gambling on the long term gains that may be associated with $R \& D$ activities. Further as stated by Rip and Groen there are "many visible hands" that are involved in the construction of new knowledge, technologies and products and it is important to understand which of these are relevant and what exactly is their contribution to the value creation process. ${ }^{20}$

It is important to understand how a knowledge intensive entrepreneurial network can survive and prosper in society while increasing not just economic wealth but also economic value. As pointed out by Van der Veen and Wakkee entrepreneurship is defined as quest for private wealth which in turn creates more wealth thereby enriching society at different levels. Entrepreneurship is the process of discovering and evaluating opportunities which in turn are exploited thereby resulting in creation of value. Although the individual entrepreneur's role is central to this process, there is nevertheless a deep influence by variables such as the society and environment. The term "value" is used instead of "wealth" by some authors in order to emphasise upon the non-economic outcomes that the entrepreneurial process can sometimes generate. ${ }^{21}$

19 GROEN, Aaard. Knowledge Intensive Entrepreneurship in Networks: Towards a Multilevel/Multi Dimensional Approach. Journal of Enterprising Culture, 2005, vol. 13 (1), pp. $69-88$ at 71.

20 GROEN, Aard, De WEERD-NEDERHOF, Petra, KERSSENS-VAN DRONGELEN, Inge, BADOUX, Rob, OLTHUIS, Gerard. Creating and Justifying Research and Development Value: Scope, Scale, Skill and Social Networking of R\&D. Creativity and Innovation Management, 2002, vol. 11, no. 1, pp. 2-16, where Rip and Groen are cited in pgs 2-3.

21 VAN DER VEEN, Marijke, WAKKEE, Ingrid. Understanding the entrepreneurial process. In WATKINS, David (ed.) Annual Review of Progress in Entrepreneurship Research. Brussels: European Foundation for Management Development, 2004, pp. 114-152. 
Values are woven into language, thought and behaviour patterns; they are based on what is important to us. Cardinal values are values that are fundamental to rest of the moral system, the values from which all other values spring. Institutional realms representing cardinal values lay in economy, polity, science, religion, ethics, and arts. Norms and values are each fundamental to a major modality in which man may find him. The first is the mode of compliance when you ask at every new turn. The second is the mode of actualizing when we ask at every turn. In authoritarian and dictatorial societies with much central planning people are expected to ask only the first set of questions. There you live a life that is to an overwhelming extent designed by others. In democracies and market economies the second set of questions is asked more often. Here you may live a life more designed by yourself. To people or organizations operating in the compliant mode the norms are most fundamental. To people or organizations in the actualizing mode their values are most fundamental. Sociologists have long known a great deal about the compliance to norms, but we know less about the actualization of values. ${ }^{22}$

In order to understand entrepreneurship one must analyse the multiple level of networks comprising of entrepreneurs, organisations and macro environment aspects which cause micro interaction patterns resulting in structural changes within networks at micro, meso and macro levels. Therefore a dynamic multi dimensional process approach is required for researching such a living system. ${ }^{23}$ Further, for valuing the impact or output of entrepreneurship, networking and the fruits of their RDI which benefit society, one can calculate the social rate of return (similar to the benefit-cost ratio method), or measure the ultimate impact that innovation-related activities can have in the context of being profitable or loss making or by measuring the output of innovation. But doing so results in ignoring the social context which is much wider in scope. ${ }^{24}$

The true value of an invention depends upon diverse factors such as its economic value, strategic value, cultural value and social value. Here the goal is to be able to deduce the gross benefit to the applicant of a technological invention or innovation. Such a valuation model would be embedded in the social systems theory. ${ }^{25}$ As stated by Groen, et al. the initiating point is that there exist

22 ZETTERBERG, Hans. The Study of Values. In SWEDBERG, Richard and UDDHAMMAR, Eric (eds). Sociological Endeavor. Selected Writings. Stockholm: City University Press, 1997, pp. 191-219.

23 GROEN, Aaard. Knowledge Intensive Entrepreneurship in Networks: Towards a Multilevel/Multi Dimensional Approach. Journal of Enterprising Culture, 2005, vol. 13 (1), pp. $69-88$ at 73.

24 DUTT, Pawan, FERRARO, Simona, CHOCHIA, Archil, MULJAR, Ramona. Using Patent Development, Education Policy and Research and Development Expenditure Policy to Understand Differences between Countries: The Case of Estonia and Finland. Baltic Journal of European Studies, 2018, 8(1), pp. 123-153.

25 LELOUX, Mirjam, GROEN, Aard. Estimating Business Value of Academic Research Outcomes: Towards a Multi-Dimensional Approach. International Journal of Technology 
actors who act purposefully in interaction with other actors. Thus in order to comprehend and value the R\&D investments within a network one must create a multiple faceted framework for analysing value creation and R\&D justification within the perspective of that network. This can be explained with the help of a framework (the so called $4 \mathrm{~S}$ framework comprising of Skills, Social Networking, Scope and Scale) which finds its roots within the multi dimensional social system theory as derived from classical sociological theory on the functional analysis of social systems. ${ }^{26}$ The social system is defined by Parsons as:

"....a social system consists in a plurality of individual actors interacting with each other in a situation which has at least a physical or environmental aspect, actors who are motivated in terms of a tendency to the "optimisation of gratification" and whose relation to their situations, including each other, is defined and mediated in terms of culturally structured and shared symbols". ${ }^{27}$

This has inspired the $4 \mathrm{~S}$ framework theoretical model of Groen et al whereby entrepreneurs strive for goal attainment by developing novel action patterns within the framework of existing patterns of behaviour which are shared within a cultural context. ${ }^{28}$ The four mechanisms embedded in the definition outlined by Parsons are interacting actors, who aim for attainment of goals, by optimising processes while maintaining specific patterns of symbols which are influenced by culture. The four dimensions are scope, scale, skill and value and finally the social network. Hence the name - the $4 \mathrm{~S}$ framework. These in turn lead to the four respective capitals. ${ }^{29}$

Mechanisms, respective dimensional aspects and related capitals ${ }^{30}$

\begin{tabular}{|c|c|c|}
\hline Mechanism & Dimensional aspect & Capital \\
\hline Strategic goal attainment & Scope & Strategic Capital \\
\hline Pattern maintenance & Skills and values & Cultural Capital \\
\hline
\end{tabular}

Transfer and Commercialisation, 2009, vol. 8(1), pp. 3-21 at 4.

26 GROEN, Aard, De WEERD-NEDERHOF, Petra, KERSSENS-VAN DRONGELEN, Inge, BADOUX, Rob, OLTHUIS, Gerard. Creating and Justifying Research and Development Value: Scope, Scale, Skill and Social Networking of R\&D. Creativity and Innovation Management, 2002, vol. 11, no. 1, pp. 2-16.

27 PARSONS, Talcott. The Social System. London: Routledge \& Kegan Paul Ltd., 1951.

28 GROEN, Aard, De WEERD-NEDERHOF, Petra, KERSSENS-VAN DRONGELEN, Inge, BADOUX, Rob, OLTHUIS, Gerard. Creating and Justifying Research and Development Value: Scope, Scale, Skill and Social Networking of R\&D. Creativity and Innovation Management, 2002, vol. 11, no. 1, pp. 2-16.

29 GROEN, Aaard. Knowledge Intensive Entrepreneurship in Networks: Towards a Multilevel/Multi Dimensional Approach. Journal of Enterprising Culture, 2005, vol. 13 (1), pp. $69-88$ at $74-75$.

30 DUTT, Pawan, FERRARO, Simona, CHOCHIA, Archil, MULJAR, Ramona. Using Patent Development, Education Policy and Research and Development Expenditure Policy to Understand Differences between Countries: The Case of Estonia and Finland. Baltic Journal of European Studies, 2018, 8(1), pp. 123-153. 


\begin{tabular}{|c|c|c|}
\hline $\begin{array}{c}\text { Efficiency adapta- } \\
\text { tion through eco- } \\
\text { nomic optimisation }\end{array}$ & Scale & Economic Capital \\
\hline Interacting actors & Social networking & Social Capital \\
\hline
\end{tabular}

The above social system theory model is dependent upon the viewpoint of entrepreneurship within networks. To relate to the above approach, one must understand how value is created through entrepreneurial processes. Shane and Venkataraman state that for this, one must begin by regarding entrepreneurship as a process where various actors interact with each other thereby recognising opportunities which reveal themselves. The actors accordingly take steps to prepare themselves to exploit such recognised opportunities and as a result create value. ${ }^{31}$ Unfortunately, the above process is not immune to tensions since resistance to such opportunities often spring up, not only from neighbouring or far flung actors but also other systems which exist within the entrenched social structure. ${ }^{32}$ The entrepreneurs act as described above and constantly strive to optimise their rewards in a continuous manner. This in turn makes their actions and processes more effective and efficient. As a result they get more integrated by interacting in a direct and indirect manner with other actors. The resulting four dimensional space leads to an accurate description of how an entrepreneur develops.

Van der Veen and Wakkee state that the motivation for seeking opportunities is fueled by dissatisfaction and is influenced by the entrepreneur's personal characteristics seen through the prism of his/her societal values and the surrounding environment. Social factors are as important as culture and personalities when it comes to discovering of opportunities. The entrepreneur needs to be alert and possess prior knowledge, but his/her success also depends upon being purposeful possessing certain personality traits and the social networks he/she can tap into. ${ }^{33}$

Thus when compared to other theories which regard resources as being linked to specific dimensions of the acts of commission and omission performed by goal oriented actors, the social systems theory approach enables the researcher to accumulate knowledge of projects with regard to multi level and multi dimensional areas, assuming that the actors are embedded within the system. ${ }^{34}$

31 VAN DER VEEN, Marijke, WAKKEE, Ingrid. Understanding the entrepreneurial process. In WATKINS, David (ed.) Annual Review of Progress in Entrepreneurship Research. Brussels: European Foundation for Management Development, 2004, pp. 114-152 at 117 where Shane and Venkataraman are cited.

32 GROEN, Aaard. Knowledge Intensive Entrepreneurship in Networks: Towards a Multilevel/Multi Dimensional Approach. Journal of Enterprising Culture, 2005, vol. 13 (1), pp. $69-88$ at 69.

33 VAN DER VEEN, Marijke, WAKKEE, Ingrid. Understanding the entrepreneurial process. In WATKINS, David (ed.) Annual Review of Progress in Entrepreneurship Research. Brussels: European Foundation for Management Development, 2004, pp. 114-152.

34 GROEN, Aaard. Knowledge Intensive Entrepreneurship in Networks: Towards a Multi- 
Entrepreneurship in Networks model ${ }^{35}$

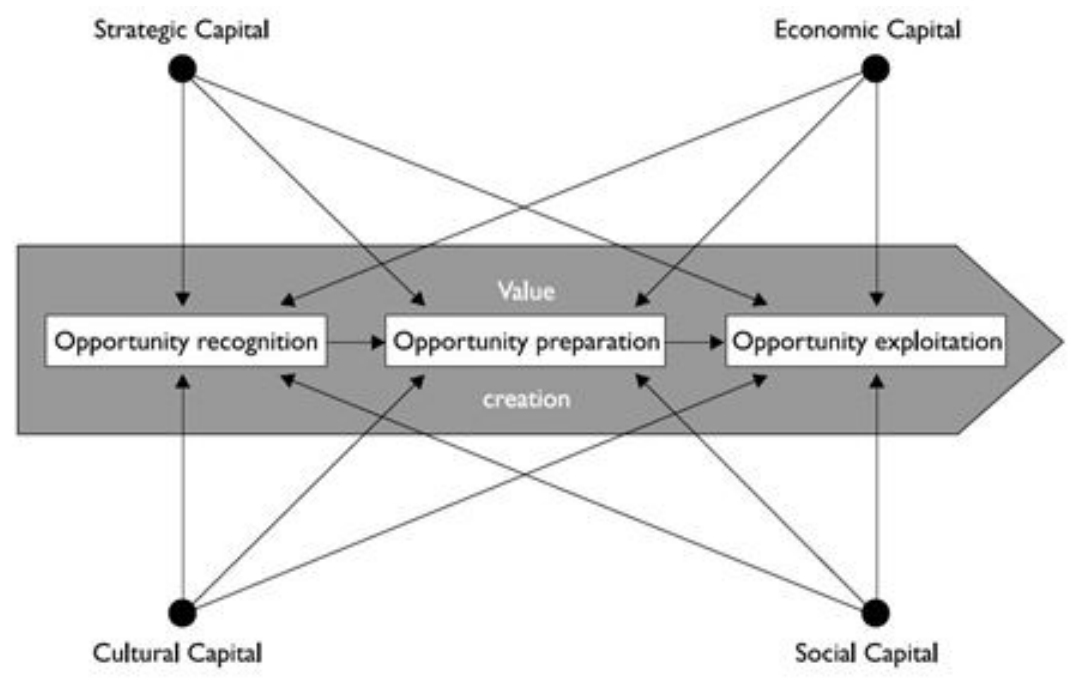

The essence of dynamic capabilities is a firm's behavioural orientation in the adaptation, renewal, reconfiguration and re-creation of resources, capabilities and core capabilities responding to external changes. ${ }^{36}$ Such dynamic resources help a firm adjust its resource mix and thereby maintain the sustainability of the firm's competitive advantage. It is plausible that the specific dynamic capability, whether problem formulation, problem solving, or solution implementation, may depend on the nature of the changing environment. ${ }^{37}$

level/Multi Dimensional Approach. Journal of Enterprising Culture, 2005, vol. 13 (1), pp. 69-88 at 82-84.

35 KIRWAN, Paul, VAN DER SIJDE, Peter, GROEN, Aard. Early-Stage Networking: How Entrepreneurs Use Their Social Capital to Establish and Develop High-Technology StartUps. In J. Ulijn, D. Drillon, \& F. Lasch (Eds.), Entrepreneurship, Cooperation and the Firm: The Emergence and Survival of High-Technology Ventures in Europe. Edward Elgar Publishing, 2007, pp. 391-414.

36 TEECE, David, PISANO, Gary, SHUEN, Amy. Dynamic Capabilities and Strategic Management. Strategic Management Journal, 1997, vol. 18, pp. 509-533.

37 NICKERSON, Jackson, YEN, James, MAHONEY, Joseph. Exploring the Problem-Finding and Problem-Solving Approach for Designing Organizations. Academy of Management Perspectives, 2012, vol. 26 no. 1, pp. 52-72. 


\section{Implications of cultural, economic, social and strategic factors towards rdi policies of enterprises and governments}

The motivation to acquire IPRs in general and patents in particular is dependent upon the intensity of competition in the market as well as the need to cooperate with research partners, competitors, suppliers, customers, etc. ${ }^{38}$

It should also be noted that state run programs which are specifically developed and designed to foster entrepreneurship are vital since entrepreneurship contributes in important ways towards a country's economic growth as well as general social welfare. ${ }^{39}$

Blind et $\mathrm{al}^{40}$ outline some motives to acquire patents:

\begin{tabular}{|c|c|}
\hline Traditional & Strategic \\
\hline $\begin{array}{c}\text { Protect an invention from } \\
\text { the risk of imitation. }\end{array}$ & $\begin{array}{c}\text { Block competitors: (a) offensively } \\
\text { by patenting to prevent competitors } \\
\text { from using the technical inventions } \\
\text { in similar or adjacent fields, or } \\
\text { (b) defensively where patent } \\
\text { portfolios are possessed solely to } \\
\text { discourage competitors or non- } \\
\text { competing third parties from filing } \\
\text { suits for infringement of patents. }\end{array}$ \\
\hline $\begin{array}{c}\text { Secure portfolio of intangible } \\
\text { assets to increase the valu- } \\
\text { ation of the enterprise. }\end{array}$ & $\begin{array}{c}\text { Use patents as indicators of RDI } \\
\text { so as to assess performance and } \\
\text { offer rewards to R\&D personnel. }\end{array}$ \\
\hline & $\begin{array}{c}\text { License patents as a } \\
\text { source for income. }\end{array}$ \\
\hline & $\begin{array}{c}\text { Exchange material for pur- } \\
\text { poses of strengthened negotia- } \\
\text { tion, cross licensing, etc. }\end{array}$ \\
\hline & Extend into international markets. \\
\hline & Build a high tech repu- \\
& tation or image. \\
\hline & $\begin{array}{c}\text { Peer pressure due to IPR } \\
\text { activities of competitors. }\end{array}$ \\
\hline & To develop and enforce standards \\
\hline
\end{tabular}

Enterprises in the electro technical sector (including ICT) generally tend to use their patents more often as strategic tools. One of the reasons for this behav-

38 BLIND, Knut, EDLER, Jakob, FRIETSCH, Rainer, SCHMOCH, Ulrich. Motives to patent: Empirical evidence from Germany. Research Policy, 2006, 35, pp. 655-672.

39 ZOLLNER, Moritz, FRITSCH, Michael, WYRWICH, Michael. An Evaluation of German Active Labor Market Policies and its Entrepreneurship Promotion. Jena Economic Research Papers. Friedrich-Schiller-University Jena, 2016-022, pp. 1-55 at 1.

40 BLIND, Knut, EDLER, Jakob, FRIETSCH, Rainer, SCHMOCH, Ulrich. Motives to patent: Empirical evidence from Germany. Research Policy, 2006, 35, pp. 655-672. 
iour could be attributed to the fact that in this sector it is very often the case that patents of others are used. Thus their patents portfolios are primarily designed to be used strategically for negotiating, cross-licensing, as currencies for technological knowledge, and to discourage new entrants in the market who have not yet built up a high mass of patents themselves and thus rely upon other technology suppliers for their subsystems. This behaviour contrasts with enterprises in the manufacturing sector who use patents to block their competitors by building patent fences. ${ }^{41}$

Strategic patenting is of immense importance in management practices of successful high tech enterprises. Simply put, RDI activities and patenting by themselves are no longer enough, since the effect of market competitiveness cannot be ignored. Instead the key is to attain maximum use of the beneficial output of RDI activities (often in the form of IP in general and patents in particular) through intelligent management practices. ${ }^{42}$

When looking at patents, it is apparent that SMEs are at a disadvantage when compared to larger enterprises. Further, SMEs in small countries such as Estonia are unable to compete with enterprises in richer countries like Germany with long traditions of IP protection and commercialisation. Thus it is important for SMEs in Estonia to be actively supported so that they can use patents effectively as protective and strategic devices. They also need support in order to deal in an efficient manner when responding to patent claims made by other enterprises.

From an RDI perspective, new start up firms generally increase the level of competition in a region. This often improves productivity, introduces innovations and new forms of technology within the market, thereby resulting in knowledge spillovers which are fundamentally important and provide the economic rationale for state sponsored subsidisation of start ups in the first place. Such subsidies could be designed to tackle lack of awareness and imperfect information regarding opportunities among unemployed persons for new forms of businesses. This could include information regarding IPR generation and exploitation. Such subsidies, if successfully implemented, are known to reduce unemployment, increase the rate of establishment of start ups and also enable the creation of new jobs. ${ }^{43}$

From a cultural and social viewpoint RDI related knowledge spillovers are very essential to create and accumulate new ideas. Thus, successful innovation policies should be aimed in such a manner that they aid in the enhancement of diffusion of knowledge and also add to the absorptive capacity of regions. Transmission of knowledge is enabled by setting up research networks and providing

41 Ibid.

42 Ibid.

43 ZOLLNER, Moritz, FRITSCH, Michael, WYRWICH, Michael. An Evaluation of German Active Labor Market Policies and its Entrepreneurship Promotion. Jena Economic Research Papers. Friedrich-Schiller-University Jena, 2016-022, pp. 1-55 at 29, 30. 
for liberal mobility schemes for skilled RDI personnel. By improving the educational level of the work force by using suitable educational policies, the ability of a region to absorb external knowledge is greatly enhanced. ${ }^{44}$ This also helps to create strategic alliances and networks which in turn can be nourished through support systems.

When a region is further away from the frontiers of high technology, then knowledge generation in such far areas is reliant on acquisition of technology either through technology diffusion aids or through the art of imitating successful regions. ${ }^{45}$

From the perspective of economic efficiency, it is important to identify and mobilise financial resources, especially state aid. The role of tax incentives, grants, subsidised loans, loan guarantees, etc especially towards activities such as IPR generation need to be carefully evaluated. In this regard, it is interesting to note that active labour market policies (such as in Germany) can be successful and also cost efficient in running several entrepreneurship promotion programs which include bridging programs and start up subsidies. ${ }^{46}$

However it should be noted that such subsidisation cannot be unfettered. State Aid is specifically restricted under the Treaty on the Functioning of the European Union (especially under Articles 107-109). Furthermore, the Technology Transfer Block Exemption Regulation (Commission Regulation (EU) No 316/2014) on the application of Article 101(3) of the Treaty to categories of technology transfer agreements restricts in some cases and directly outlaws in other cases any anti-competitive practices related to patent licensing. This regulation especially affects behaviour of dominant undertakings and their relationships with their competitors/ non-competitors in respect of strategic activities (as outlined in the guidelines 2014/C 89/03) such as cross licensing, royalty obligations, exclusive licensing practices, restrictions (regarding sales, output, field of use and captive use), non-competition obligations, technology pools, technology standards, etc.

\section{A comparison of estonia with Germany}

\subsection{Brief introduction}

Estonia and Germany share a long historical connection. Estonian history has for many centuries been marked by foreign powers, in terms of law start-

44 SANSO-NAVARRO, Marcos, VERA-CABELLO María. The long-run relationship between R\&D and regional knowledge: the case of France, Germany, Italy and Spain. Regional Studies, 2018, 52:5, pp 619-631 at 630.

45 Ibid at pg. 629.

46 ZOLLNER, Moritz, FRITSCH, Michael, WYRWICH, Michael. An Evaluation of German Active Labor Market Policies and its Entrepreneurship Promotion. Jena Economic Research Papers. Friedrich-Schiller-University Jena, 2016-022, pp. 1-55. 
ing with the conquest of Livonia (and after 1346 also of the until then Danish-ruled Northern Estonian territories) by the German Order of the Brethren of the Sword (later joining the Teutonic order) in the early thirteenth century. The Order-just as German merchants and noblemen mainly from Westphalia and the Northern Rhine region settling soon after in the soon rapidly developing Hanseatic cities of Dorpat (Tartu), Reval (Tallinn), Pernau (Pärnu), Fellin (Viljandi) and Narva-brought with them their local German laws, which were either based on/strongly influenced by Eike von Repgov's Sachsenspiegel (created between 1220 and 1235) or the City statutes of the respective home Hanseatic cities (mainly Bremen, Hamburg and Lübeck). Although there were several changes among the rulers, German nobility had the biggest effect to the legal society until the 1860s. German jurisprudence did not only survive the social and political upheavals of the early twentieth century, but remained in force even during the subsequent period of Estonian independence. ${ }^{47}$

Both Estonia and Germany are presently members of the EU, Eurozone, North Atlantic Treaty Organisation and Schengen. As per the International Monetary Fund, in terms of Gross Domestic Product (GDP) at current prices, Germany has a GDP of 3.96 thousand Billion US Dollars. Estonia has a GDP of 31.03 Billion US Dollars. ${ }^{48}$

\subsection{Description of Germany's patent system, education system and RDI policies}

(i) History of patenting in Germany

The unification of Germany occurred in 1871. In 1877, the Imperial Patent Office was established under a new Patent Act. It was a central office which dealt uniformly with patent affairs for all the 25 odd states throughout the German Empire. The patents were granted on uniform principles and had a unitary effect throughout the German Empire. Inspired by the British model, the patents were published after grant. This period also saw a great level of advancement in the industrialisation of Germany, just as in other European countries. The German chemical industry encouraged the amendment of the Patent Act in 1891 so that product and process patent could be issued. This led to an increase in patent applications between the period 1891-1900. The efficiency of the Patent Office in areas of organisation, administration and preliminary examination were also improved. From the very early stages it was recognised that industrial progress and patent protection in Germany were closely connected. In 1903 Germany

47 EVAS, Tatjana, HOFFMANN, Thomas, JOAMETS, Kristi, KERIKMAE, Tanel, LOIK, Ramon, NYMAN-METCALF, Katrin, POPOV, Aleksandr, SARAV, Sandra. General Frameworks. In KERIKMAE, Tanel, JOAMETS, Kristi, RODINA, Anita, PLEPS, Janis, GRUODYTE, Edita (eds). The Law of the Baltic States, Springer Verlag, 2018, pp. 41-100 at 3-7.

48 International Monetary Fund. Datasets GDP Current Prices. [online]. Available at: https:// www.imf.org/external/datamapper/NGDPD@WEO/OEMDC/ADVEC/WEOWORLD/ EU/EUQ Accessed: 14.06.2019 
was able to showcase its modernity by becoming party to the Paris Convention of $1883 .^{49}$

Privately funded RDI centres such as Bayer's research lab had a portfolio of over 8000 patents in 1913. The unified patent legislation from 1877 was beneficial because incentives for research were created, technology transfer was encouraged due to possibility of trading in innovations and technology was widely distributable. Copious funding (made available thanks to the French war repatriation payments made after the Franco-Prussian War) within the German Empire was made available to bankers and railways, thereby boosting German innovation efforts and the commercialisation thereof. ${ }^{50}$

In 1914 World War 1 was declared and this prevented further reform in the German patent laws. In 1919, as the German Empire collapsed there was widespread mayhem and unemployment. But by 1924 the German economy improved and more patenting activity took place. This peaked in 1930 before the Nazi government's rearmament policies and the subsequent second World War resulted in the complete ruin and division of Germany. During the Cold War period, East and West Germany had almost identical legal provisions due to East Germany's membership of the international IP organisations. However, it was only in West Germany that the patent office truly worked in a capitalist environment starting from 1948. In the Federal Republic of Germany (FRG), the patent office was responsible for patenting activities and also offering advisory and conciliatory services for disputes. ${ }^{51}$

The German economy and its institutions were badly affected by both World Wars. Although the corporates and higher educational structure managed to barely survive, the occupying Allied forces restricted German RDI activities of the renamed Max Planck Institutes to strictly basic research. To fill this gap, the Fraunhofer Society was established in 1949 to conduct applied research and improve industrial competitiveness of Germany. ${ }^{52}$

In 1961 the Federal Patent Court consisting of judges who were experts in technical and legal fields was set up in FRG. Further changes took place in 1967 leading to isolated searches and deferred examinations. In the 1970s, FRG signed various important international agreements including the Patent Cooperation

49 German Patent and Trade Mark Office. 140 years of the patent office in Germany. [online]. Available at: https://www.dpma.de/english/our_office/about_us/history/140yearsofthepat entoffice/index.html Accessed: 14.06.2019

50 NAUDE, Wim, NAGLER, Paula, Technological Innovation and Inclusive Growth in Germany. IZA Discussion Paper, 2017, No. 11194, pp. 1-53 at 10, 11, 12.

51 German Patent and Trade Mark Office. 140 years of the patent office in Germany. [online]. Available at: https://www.dpma.de/english/our_office/about_us/history/140yearsofthepat entoffice/index.html Accessed: 14.06.2019

52 NAUDE, Wim, NAGLER, Paula, Technological Innovation and Inclusive Growth in Germany. IZA Discussion Paper, 2017, No. 11194, pp. 1-53 at 13. 
Treaty. The formation of the European Patent Office led to great demand for the highly experienced German patent examiners who joined it in droves due to its lucrative offers. After German reunification in 1990, the German Patent office once again became a single entity. Hopes of turning the former East Germany into a thriving economic story were however dashed as most companies in the East either shut down or relocated to the west. German patent applications declined when compared with USA or Japan. Since 1998, the patent office is known as Deutsches Patent - und Markenamt (DPMA) and is the fifth largest in the world. ${ }^{53}$

(ii) The German education system

One can see the emphasis on cultural, economic, social and strategic capitals in German public policies. A good example of the above is the German education system. The German education system combined with vocational education training (VET) programs is the key aspect of its cultural and social aspects. The schools are primarily run by the states. After age 10, students are channelised into secondary general schools (Hauptschulen) to prepare for VET or into grammar schools (Gymnasien) to receive a more academic education in order to enter universities. Higher education focuses on graduates in specialised fields such as engineering, manufacturing and construction. Elite universities have emerged with increased funding made available to them in 2007-2011. It was hoped to diversify research goals. Although the above resulted in increasing competition for funding between universities, it did not diversify research projects. The VET system is based on dual training whereby the apprentice trains in a company and also attends vocational training schools to get theoretical and practical knowledge. Thus state agencies, employers and unions organise and run the vocational skills system which makes the workforce highly valued with standardised skill sets. This suits German industries such as vehicles and mechanical engineering where firm specific skills, long job tenures and industry collective wage agreements are the norm. Germany spends much more on tertiary level students than on primary and secondary levels. ${ }^{54}$

German education system attracts much praise. However it does not fare very highly in terms of global skills rankings such as Global Talent Index. Similarly, in the Global Index of Cognitive Skills and Educational Attainment measured by PISA (Program for International Student Assessment), PIRLS (Progress in International Reading Literacy Study) and TIMMS (Trends in International Mathematics and Science Study), Germany is ranked surprisingly low. ${ }^{55}$ As per

53 German Patent and Trade Mark Office. 140 years of the patent office in Germany. [online]. Available at: https://www.dpma.de/english/our_office/about_us/history/140yearsofthepat entoffice/index.html Accessed: 14.06.2019

54 ALLEN, Mathew. Germany's National Innovation System. In Encyclopaedia of Technology and Innovation. Oxford: Basil Blackwell, 2009, pp. 375-389 at 384-388.

55 NAUDE, Wim, NAGLER, Paula, Technological Innovation and Inclusive Growth in Germany. IZA Discussion Paper, 2017, No. 11194, pp. 1-53 at 25. 
the Global Creativity Index 2015, by using the number of patent applications per million people as the standard for measurement of innovation, Germany stands in the 10 th position. ${ }^{56}$

(iii) Developments in the past few decades regarding technological innovation and its funding in Germany

Germany's innovation system is derived from the $19^{\text {th }}$ century practices of apprenticeship and has evolved from close cooperation between universities and companies. Germany's strength continues to be in industries related with vehicles, mechanical engineering, electrical and chemical industries. The western part of Germany is still more developed than the eastern part. German research institutions play an important role by promoting excellence in research activities, optimising gains from investments and targeting funds towards actors who are best positioned to deliver the optimal results. ${ }^{57}$

The negative productivity shock caused by the reunification of Germany has severely affected the labour productivity growth which was already in decline. ${ }^{58}$ German R\&D expenditure is below the recommended 3 percent of GDP even though Germany invests more than other EU countries. It is comparable with the sum of money spent by US and Japan on R\&D. Germany has strived to spend more on RDI in areas that are ignored by its commercial enterprises. A survey of German patents shows that its main strength lies in medium to high tech industries such as automobiles, mechanical engineering, electronics, etc. It should be noted that these are the industries which first emerged in the $19^{\text {th }}$ century. However, in the 2000s German patents in the field of new and cutting edge technologies such as biotech, ICT, pharmaceuticals, etc were comparatively weaker. Since these were the very areas which were expected to be of high significance in the future, several reforms were designed and initiated in the German innovation system. ${ }^{59}$ It should be noted that the term "Fourth Industrial Revolution" was originally coined by the German engineer and founder of the World Economic Forum, Professor Klaus Schwab. Industrie 4.0 will challenge us in how to reinvent jobs in a world where machines will take our jobs, work will be less centralized, more fluid, more project oriented, and more virtual and international. ${ }^{60}$

56 FLORIDA, Richard, MELLANDER Charlotta, KING, Karen. Global Creativity Index [online]. Available at: http://martinprosperity.org/wp-content/uploads/2011/10/Creativity-and-Prosperity_The-Global-Creativity-Index.pdf Accessed: 14.06.2019 at pg. 13.

57 ALLEN, Mathew. Germany's National Innovation System. In Encyclopaedia of Technology and Innovation. Oxford: Basil Blackwell, 2009, pp. 375-389 at 375

58 NAUDE, Wim, NAGLER, Paula, Technological Innovation and Inclusive Growth in Germany. IZA Discussion Paper, 2017, No. 11194, pp. 1-53 at 3.

59 ALLEN, Mathew. Germany's National Innovation System. In Encyclopaedia of Technology and Innovation. Oxford: Basil Blackwell, 2009, pp. 375-389 at 378.

60 SAP. Production of the future: How to Prepare for the Fourth Industrial Revolution. Walldorf: SAP. 2013. 
In order to be prepared for the fourth industrial revolution the development of a strategic knowledge vision is needed. ${ }^{61}$

Some of the key Government funded umbrella organisations for the benefit of research institutes are as follows: ${ }^{62}$

\begin{tabular}{|c|c|}
\hline Institution & Activities \\
\hline \multirow{3}{*}{ The Science Council } & $\begin{array}{c}\text { Coordinating with and } \\
\text { advising how to develop insti- } \\
\text { tutions of higher education, } \\
\text { science and research. Evaluation } \\
\text { and accreditation of research } \\
\text { institutes, universities, etc. }\end{array}$ \\
\hline Central body which awards \\
grants and financial support \\
The German \\
for research activities in higher \\
education, especially universities \\
and public funded RDI institutes. \\
Supports early career research- \\
ers and promotes international \\
links among research centres.
\end{tabular}

61 WAHL, Mike. Strategic Factor Analysis for Industry 4.0. Journal of Security and Sustainability Issues, 2015. Vol 5, no. 2, pp 241-247.

62 ALLEN, Mathew. Germany's National Innovation System. In Encyclopaedia of Technology and Innovation. Oxford: Basil Blackwell, 2009, pp. 375-389 at 376-378. 


\begin{tabular}{|c|c|}
\hline The Fraunhofer Society & $\begin{array}{l}\text { It generally conducts applied } \\
\text { research activities for public and } \\
\text { private enterprises on a con- } \\
\text { tractual basis in order to enable } \\
\text { commercialisation of RDI. It } \\
\text { has strong links to industries. }\end{array}$ \\
\hline $\begin{array}{l}\text { The Leibniz Sci- } \\
\text { ence Association }\end{array}$ & $\begin{array}{l}\text { It comprises of research cen- } \\
\text { tres which conduct independ- } \\
\text { ent research and also provide } \\
\text { support services. It links basic } \\
\text { and applied research activities } \\
\text { in Germany by forming regional } \\
\text { clusters of universities, conduct- } \\
\text { ing inter disciplinary research } \\
\text { into areas of future importance } \\
\text { and by forming working groups. }\end{array}$ \\
\hline $\begin{array}{l}\text { The Centre for Advanced } \\
\text { European Studies and } \\
\text { Research Foundation }\end{array}$ & $\begin{array}{l}\text { It focusses on successfully } \\
\text { commercialising RDI in new } \\
\text { areas such as nanotechnol- } \\
\text { ogy, biotechnology, etc. }\end{array}$ \\
\hline
\end{tabular}

In Germany, start up funding comes in the form of specialised subsidies for varying durations which help new firms financially so that they may develop more easily during the early phases of their existence. The first of the German aid projects, namely the Bridging Allowance, was introduced in 1986 to help highly qualified unemployed people to commence their own businesses. The German reunification process resulted in serious economic problems which were sought to be countered by the Hartz Reforms of the 2000s. The purpose was to modernize the German labour market and to assist unemployed individuals. In 2003, the Start up Subsidy was introduced to help less educated unemployed persons. In 2006, both the above were combined into the New Start up Subsidy in order to simplify the entire process. The key requirement is that there should exist a business plan which is sustainable and is positively evaluated by the Chamber of Industry and Commerce. Also important is the requirement of participation in seminars specially designed for start ups. ${ }^{63}$

On a similar note, in 2001 the German government strategically focussed on commercial exploitation, spinoffs and research related startups, collaborative partnerships between research institutes and private enterprises, and competence in order to enable the use of RDI results in innovation processes of firms. For the purposes of exploitation, special patent and exploitation agencies were set up in order to enable patenting of inventions created by German universities.

63 ZOLLNER, Moritz, FRITSCH, Michael, WYRWICH, Michael. An Evaluation of German Active Labor Market Policies and its Entrepreneurship Promotion. Jena Economic Research Papers. Friedrich-Schiller-University Jena, 2016-022, pp. 1-55 at 6, 13 and 14. 
This centralisation was intended to help individual universities which often lack adequate resources for IP protection. The teachers' privilege was also abolished in 2002 so that inventions would now be owned by their employer (the university) and the university researcher would receive 30 percent of the gross income. More public funds were made available to support researchers who wished to set up their own startups. A favourable environment for startups was created by providing for mentorship programs, awards for entrepreneurs and by setting up professorial chairs in entrepreneurship studies in higher educational institutions. A key change to funding regulations required all projects to have clear cut plans for exploitation of RDI output which needed to be implemented. ICT training was also enhanced in vocational training centres. ${ }^{64}$

The main aspects of the national technology policy of Germany were establishing objectives for researchers in public and private sectors, improving expensive RDI infrastructure and improving skills and capabilities of researchers. ${ }^{65}$

In this regard the High Tech Strategy for Germany was unveiled in 2006. It defined goals for 17 key technology fields which were deemed to be important from the future perspective. It emphasised upon greater collaboration between public and private research institutes and enterprises and to form clusters which focus on cutting edge technologies. Commercialisation of RDI outputs was hoped to be achieved by simplifying the assessment criteria of economic viability and valuation of research projects. Innovation oriented startups and SMEs were provided generous assistance in the form of easy market access, improved linkages between commercial enterprises and research institutes, support for commercialisation of their innovations, and increased State Aid to SMEs in the form of corporate tax relief and eased access to Venture Capital (VC) funding. ${ }^{66}$

With regards to funding, in 2005 the Joint Initiative for Research and Innovation was launched to increase funding for the above mentioned research institutes. New and unconventional projects along with clusters were prioritised for funding purposes. As per the Lisbon strategy of the EU, the aim was to increase expenditure on RDI in Germany in the future to $3 \%$ of GDP from the $2.5 \%$ of GDP in 2007. 6000 million Euros additional public funding was provided between 2006-2009 to stimulate innovation to make up for the short fall of interest shown by private enterprises to fund RDI in long term research projects whose end results are often difficult to predict. The above sum was focused on research areas such as ICT, energy, biotechnology and nanotechnology that were predicted to show the most economic potential and job growth in the future. Similarly the High Tech Startup Promotion Fund was set up in 2006 to provide seed funding upto 1 million Euros in equity funding to encourage new knowledge intensive

64 ALLEN, Mathew. Germany’s National Innovation System. In Encyclopaedia of Technology and Innovation. Oxford: Basil Blackwell, 2009, pp. 375-389 at 379-381.

65 Ibid at pg. 381.

66 Ibid at pg. 381-382. 
enterprises which focus on cutting edge technologies. Most of these funds came from the Federal or state budgets. Efforts were made to increase VC funding in Germany. This was deemed especially important since there was far more VC funding available in UK and USA than in Germany. ${ }^{67}$

It should be noted that in Germany VC funding is uncommon because German companies were usually financed using the bank-based system instead of the market-based system. Banks focused on long term returns which were suitable for German industries such as vehicles and mechanical engineering which relied upon incremental innovations instead of radical ones. ${ }^{68}$

Worryingly, nowadays rather than ploughing their money into capital investments or breakthrough innovations, large German corporations prefer to hoard vast amounts of cash reserves. ${ }^{69}$ Although domestic demand has stagnated, Germany has been able to export more, mostly thanks to the Euro exchange rate which has proven to be beneficial for Germany. By shifting low skilled production to offshore areas, German firms have managed to reduce their demand for labor which requires low skills. Instead they have concentrated upon meeting their high skilled labor needs. ${ }^{70}$

\section{(iv) A critical view of the state of affairs in German RDI activities}

Between the period from 1850 upto the start of World War 1, Germany's enviable and fast paced industrialisation was enabled by the unique triple-helix system of collaborating industries, higher education institutions and the government. This model persisted even after World War 2, but now is regarded by some researchers to be outdated since it cannot produce innovations of the fourth industrial revolution due to rigidity, lack of diversity in higher education and low appetite for risk taking/ exploration in public organisations vis a vis VC funds. ${ }^{71}$

From a historical perspective one can see that although technological innovation has been the key to Germany's success, upto the early years of the $20^{\text {th }}$ century German enterprises excelled in radical innovations (for example the spark plug by Bosch, the internal combustion engine by Daimler, the Diesel engine by Diesel, the dry cell battery by Gassner, the antenna by Hertz, steel by Krupp, the needle telegraph by Siemens, lens manufacturing by Zeiss, etc). These scientific breakthroughs in science and engineering universities were quickly commercialised by private entrepreneurs. However, after World War 2, technological innovations in Germany have become more incremental and process oriented. ${ }^{72}$

67 Ibid at pg. 382-383.

68 HALL, Peter, SOSKICE, David. Varieties of Capitalism: The Institutional Foundations of Comparative Advantage. Oxford University Press; 2001.

69 NAUDE, Wim, NAGLER, Paula, Technological Innovation and Inclusive Growth in Germany. IZA Discussion Paper, 2017, No. 11194, pp. 1-53 at 4.

70 Ibid at pg. 5.

71 Ibid at pg. 6.

72 Ibid at pg. 6, 8, 9. 
During the period from 1993-2003, there was economic stagnation in Germany. This was overcome with the Hartz IV Reforms in 2003 which reduced government assistance for those who were unemployed or financially underprivileged, made job terminations easier and aided in the creation of non-unionised, low income jobs, etc. ${ }^{73}$

$\mathrm{R} \& \mathrm{D}$ expenditure of the older and established giant firms has been defensive in nature for several decades and has focussed on keeping new competitors out, instead of creation of new markets. Similarly, German SMEs (Mittelstand) which account for almost 70 percent of total German exports focus on improving/perfecting their existing line of goods and services to meet their customer's demands and are not interested in introducing new products. ${ }^{74}$

It should be noted that Germany's lead in new innovations of the Fourth Industrial Revolution (such as ICT, semiconductors, nanotechnology, robotics, biotechnology, etc) is non existent. This is indicated by the fact that since the 1970s not a single German firm has been an applicant for the top 20 patents in the field of nanotechnology. In the case of solar photo voltaic energy, most production shifted from Germany to China and almost 50 percent German workers lost their jobs in this field in 2013 alone. Germany's strengths lying in traditional areas such as automobiles and machine tools are affected in a fundamental manner by the new fourth industrial revolution innovations, thereby raising the spectre of Germany's manufacturing sector playing second fiddle to the US IT sector. $^{75}$

Although government funding for RDI purposes in order to stimulate technological innovation is going up rapidly (for example government RDI funding increased by 66 percent between the years 2000 to 2014), the general levels of innovativeness in Germany have declined. ${ }^{76}$ An indication of this malaise is that the quality of US Patent and Trademark Office (USPTO) patents granted to German applicants has declined as compared to US patentees. ${ }^{77}$ This decline may be explained by lack of radical innovations in the ICT sector (described as the third industrial revolution) since the 1990s. ${ }^{78}$

73 DUBNER, Stephen. What Are the Secrets of the German Economy - and Should We Steal Them? [online]. Available at: http://freakonomics.com/podcast/secrets-german-economysteal/ Accessed: 14.06.2019

74 NAUDE, Wim, NAGLER, Paula, Technological Innovation and Inclusive Growth in Germany. IZA Discussion Paper, 2017, No. 11194, pp. 1-53 at 15.

75 Ibid at pg. 5-6

76 Ibid at pg. 16.

77 KWON, Aoonwoo, LEE, Jihong, LEE, Sokbae. International Trends in Technological Progress: Evidence from Patent Citations, 1980-2011. The Economic Journal, 2017, vol. 127, issue 605, pp. F50-F70 at 56.

78 NAUDE, Wim, NAGLER, Paula, Technological Innovation and Inclusive Growth in Germany. IZA Discussion Paper, 2017, No. 11194, pp. 1-53 at 18. 
VC investment (as a percent of GDP) in USA during 2007-2016 dwarfs similar investment in Germany by almost 20 times. Further during 2014, in just 2 US cities of San Francisco and New York, VC investment was 10 times the total VC investment in Germany. In Beijing, VC investments in 2014 were double than those in Germany. ${ }^{79}$ This lack of VC activity in Germany could be seen as a symptom of innovation crisis in Germany.

However, inspite of the above shortcomings, it should be noted that the German economy continues to be strong. According to some experts, Germany's position as the world's top innovator is due in part to the sheer number of ideas it comes up with - many in the automobile industry, where it's focusing on digitally-networked mobility, driverless vehicles and electric mobility. ${ }^{80}$

It is apparent from a study of the literature that Germany took steps over the past several decades in the social and strategic context to safeguard it's manufacturing, mining and construction sector which accounts for 23 percent of its GDP and employs almost 28 percent of its workforce. ${ }^{81}$

Germany still maintains the largest trade surplus in the world (unlike USA). Germany has also achieved a distribution of economic activity all across the country in cities like Munich, Hamburg, Frankfurt, etc. rather than just concentrating in certain industrial pockets. ${ }^{82}$

Since the 1990s large German firms have successfully moved parts of their production chains to Eastern Europe and have employed workers there who are not only skilled but also work for lower wages. This has enhanced the global competitiveness of German firms. ${ }^{83}$ This is unlike in the case of USA which since the 1970s allowed the forces of globalization and financialisation of the economy to whittle down its manufacturing sector through offshoring of manufacturing and encouraged financial services instead. ${ }^{84}$

Germany's active labour market policies have been successful and also cost efficient in running several entrepreneurship promotion programs which include bridging programs and start up subsidies. Their subsequent evaluations

79 Ibid at pg. 22-23.

80 World Economic Forum. Germany is the world's most innovative economy. [online]. Available at: https://www.weforum.org/agenda/2018/10/germany-is-the-worlds-most-innovative-economy/ Accessed: 14.06.2019

81 NAUDE, Wim, NAGLER, Paula, Technological Innovation and Inclusive Growth in Germany. IZA Discussion Paper, 2017, No. 11194, pp. 1-53 at 25.

82 DUBNER, Stephen. What Are the Secrets of the German Economy - and Should We Steal Them? [online]. Available at: http://freakonomics.com/podcast/secrets-german-economysteal/ Accessed: 14.06.2019

83 MARIN, Dalia. Inequality in Germany: How it differs from the US. [online]. Available at: https://voxeu.org/article/inequality-germany-how-it-differs-us Accessed: 14.06.2019

84 BAILY, Martin, BOSWORTH, Barry. US Manufacturing: Understanding Its Past and Its Potential Future. Journal of Economic Perspectives, American Economic Association, 2014, vol. 28 , no. 1 , pp. $3-26$ at 3,4 . 
have been generally positive. The biggest issue has been the need for simplicity and transparency in the selection process for recipients of the aid. ${ }^{85}$

A survey of German companies has shown that patents are increasingly relevant for strategic objectives, the focus being clearly towards using patents for the purposes of cooperating or competing in the market. The trend reveals that large German companies view and treat their patent portfolios differently when compared with smaller companies. ${ }^{86}$

Analysis in Germany has also shown that the subsidised start ups enjoy extremely high rates of survival, vis a vis new businesses which are not recipients of such subsidies. ${ }^{87}$

\subsection{Comparison with Estonia}

(i) Foreign influences on Patent law in Estonia

During the Czarist era, Estonia was a part of the Russian Empire. The Czars tried to modernise Russia along Western lines. Accordingly, efforts were made to recognise and protect IPRs as per Western standards. Author's rights were legally protected starting from 1828 . The modern patent system and inventions/ improvements thereunder were regulated by a law enacted in 1896. Reformation of copyright law was initiated in 1911. Eventually, the Bolshevik Revolution of 1917 enforced Socialist ideals. ${ }^{88}$

After a brief war of independence, Estonia became an independent nation in 1920. The Patent Act came into force in 1921 and regulated all patenting activities until 1937. Historically, foreign patent applications were the mainstay of the Estonian Patent Office since local inventions were not considered to be inventive enough. Further, the high patent fees often deterred local interest. In 1924 Estonia acceded to the Paris Convention and later to the Berne Convention in 1927. In 1937 a new Patent Act was enacted. It was inspired by the German patent system. In 1940, with World War 2 in progress, the Estonian patent system ceased to exist. ${ }^{89}$

85 ZOLLNER, Moritz, FRITSCH, Michael, WYRWICH, Michael. An Evaluation of German Active Labor Market Policies and its Entrepreneurship Promotion. Jena Economic Research Papers. Friedrich-Schiller-University Jena, 2016-022, pp. 1-55 at 2.

86 BLIND, Knut, EDLER, Jakob, FRIETSCH, Rainer, SCHMOCH, Ulrich. Motives to patent: Empirical evidence from Germany. Research Policy, 2006, 35, pp. 655-672 at 2.

87 ZOLLNER, Moritz, FRITSCH, Michael, WYRWICH, Michael. An Evaluation of German Active Labor Market Policies and its Entrepreneurship Promotion. Jena Economic Research Papers. Friedrich-Schiller-University Jena, 2016-022, pp. 1-55 at 37.

88 EUGSTER, Esprit. Evolution and Enforcement of Intellectual Property Law in Russia. Washington University Global Studies Law Review, 2010, vol. 9, issue 1, pp. 131-151 at 136, 137.

89 Estonian Patent Office. Establishment of the Estonian Patent Office. [online]. Available at: https://www.epa.ee/en/patent-office/establishment-estonian-patent-office Accessed: 14.06.2019 
During the era of Soviet occupation, Estonia was subject to Soviet laws related to IPRs. The Soviet IPR system was different from international standards. The Civil Code of 1964 regulated author's rights in the Soviet Union. ${ }^{90}$

Estonia regained its independence in 1991. The Patents Act was enacted in 1994 and forms the legal basis for the functioning of the patent system in Estonia. Estonia became a member of the European Patent Office in 2002 and has ratified the Unitary Patent Court Agreement in 2017. Estonian and German patent laws are fully compliant with the European Patent Convention of 1973.

(ii) A critical view of the state of affairs in Estonian RDI activities

RDI in Estonia is largely dependent upon EU funding, since local funds are scarce. Such dependence results in cycles of highs and lows due to EU funding flows. Much of the modern RDI infrastructure is supported by EU. In 2011, due to a spurt of oil-shale related RDI activities, public and private funded RDI activities reached a high of $2.3 \%$ of Estonia's GDP. This dropped to $1.3 \%$ in 2017. Like in most Central and East European EU member states, there is a realisation that over reliance on EU structural funds for RDI purposes is not sustainable and eventually funding will have to be raised from domestic sources. ${ }^{91}$

Estonia has constantly struggled to maintain public expenditure on RDI related activities around the EU average. In 2017, not only was the above situation the norm but also business investment was much lower at around 0.61 percent of the GDP (roughly half the average as seen in other EU member states). ${ }^{92}$ It was hoped that the government would spend upto 1 percent of the GDP on RDI. The Estonian Research and Development and Innovation Strategy 20142020 "Knowledge-based Estonia" approved by the Estonian Parliament in January 2014 outlined a lot of visions and objectives, with targets of achieving public plus private sector investment in RDI to the tune of 3\% of the Estonian GDP, gains in the EU innovation Union Scoreboard, etc. ${ }^{93}$ However, in May 2019, the government of Estonia announced that only 0.71 percent of the GDP would be available for RDI activities for the next coming years, much to the disappointment of the research and academic fraternity in Estonia. ${ }^{94}$ This is still far short

90 EUGSTER, Esprit. Evolution and Enforcement of Intellectual Property Law in Russia. Washington University Global Studies Law Review, 2010, vol. 9, issue 1, pp. 131-151 at 140.

91 SCHIERMEIER, Quirin. How Estonia Blazed a Trail in Science. [online]. Available at: https://www.nature.com/articles/d41586-019-00209-7?fbclid=IwAR3Pzwg_gjnmPRcVSA9HcFgE7I3KgZ61SaoqLtJLOlqPhL67OmuPdFroUlM Accessed: 14.06.2019

92 European Commission. Council Recommendation on the 2019 National Reform Programme of Estonia and delivering a Council opinion on the 2019 Stability Programme of Estonia. [online]. Available at: https://eur-lex.europa.eu/legal-content/EN/TXT/?qid=1560258145 940\&uri=CELEX\%3A52019DC0506 Accessed: 14.06.2019

93 Ministry of Education and Research. Estonian Research and Development and Innovation Strategy 2014-2020 "Knowledge-based Estonia". [online]. Available at: https://www.hm.ee/ sites/default/files/estonian_rdi_strategy_2014-2020.pdf Accessed: 14.06.2019

94 WHYTE, Andrew. Academic unions call one-hour strike for June 5. [online]. Available at: 
of the recommended RDI support of around 3 percent of the GDP, as envisaged in the Europe 2020 Strategy. ${ }^{95}$

Estonia has tried to stimulate start up activities within the territory of Estonia by encouraging private investors as startups are recognised to be the key drivers for innovation activities and are perceived as being highly beneficial to society. The Estonian Development Fund since 2008 has aimed to develop the VC market in Estonia by directly funding startups. From 2017 onwards, capital was provided by Estonia through special funds to private VC funds instead, the idea being that the state can be a passive yet influential investor in VC funds. The Investment Funds Act of 2016 regulates the establishment and management of such investment funds. So far over 150 million Euros worth of assets are managed by Estonian VC funds in companies such as Cleveron, Monese, etc. The sources for this government support are EU programs and state assets and are coupled with capital from private investors such as pension funds. etc. ${ }^{96} \mathrm{How}$ ever, as the statistics reveal, a lot more still needs to be done to encourage RDI spending in Estonia.

(iii) Some comparative statistics

(a) In Simona et al, patent data was obtained from the OECD database for the years 1990-2015 showing the number of triadic patents for 26 countries. Triadic patents were used as an indicator for assessing technological strengths of nations. Triadic patents are those patents registered in the triad regions, i.e. in North America, Europe, and Asia with "priority date" where priority date means that when a first application is submitted in a country - the priority - is then extended to other offices. The variables collected were the number of patents for each country, the population level, the education level as indicator for education policy and highest level of education completed by each person, the expenditure for each country in $\mathrm{R} \& \mathrm{D}$ as gross domestic expenditure on $\mathrm{R} \& \mathrm{D}$ and as a percentage of GDP and the expenditure for R\&D personnel. The data showed that Estonia lagged behind Germany in respect of almost all variables. This is not surprising, considering the size of the German nation and its economy. The impact of cultural, economic, social and strategic capitals is also relevant to get a 360 degrees view. ${ }^{97}$

https://news.err.ee/946791/academic-unions-call-one-hour-strike-for-june-5 Accessed: 14.06.2019

95 European Commission. Europe 2020 Strategy. [online]. Available at: https://ec.europa.eu/ info/business-economy-euro/economic-and-fiscal-policy-coordination/eu-economicgovernance-monitoring-prevention-correction/european-semester/framework/europe2020-strategy_en Accessed: 14.06.2019

96 PLANTERA, Federico. SmartCap - Investing local, thinking global. Interview with Sille Pettai. [online]. Available at: https://www.startupestonia.ee/blog/smartcap-investing-localthinking-global-interview-with-sille-pettai Accessed: 14.06.2019

97 FERRARO, Simona, DUTT, Pawan, KERIKMAE, Tanel. Using Patent Development, Education Policy and Research and Development Expenditure Policy to Increase Techno- 
(b) When looking at the number of triadic patent applications filed based on the applicant's country of residence, the following information is available in the OECD database. ${ }^{98}$ Priority date for these triadic patent applications is set at 2013 because data is available only upto that date in EPO, USPTO and Japanese Patent Office (JPO) due to legal reasons. An applicant is defined as the owner of the patent at the date of application. The applicant could be a natural person or a legal person. This type of data shows the innovativeness of local firms, notwithstanding the location of their R\&D facilities.

\begin{tabular}{|c|c|c|}
\hline Year & Germany & Estonia \\
\hline 2000 & 5760.05 & 0.125 \\
\hline 2001 & 5208.2591 & 2.0833 \\
\hline 2002 & 5688.9023 & 0.3929 \\
\hline 2003 & 5870.3004 & 2.6667 \\
\hline 2004 & 6376.4783 & 1.4167 \\
\hline 2005 & 6623.9605 & 2.3296 \\
\hline 2006 & 6211.2488 & 6.353 \\
\hline 2007 & 5600.0398 & 3.669 \\
\hline 2008 & 5340.5165 & 4.181 \\
\hline 2009 & 5478.3676 & 2.8083 \\
\hline 2010 & 4978.5001 & 3 \\
\hline 2011 & 4663.0903 & 5.2345 \\
\hline 2012 & 4290.2713 & 3.5 \\
\hline 2013 & 4565.7281 & 8.5 \\
\hline
\end{tabular}

Once again, it can be seen that Estonia lags behind Germany in respect of international patents. International patents can be considered as an important indicator of high value RDI output which has great potential to be commercialised on an international level.

(c) When comparing ranking in the global technology index, we see the following difference in ranks between Germany and Estonia in respect of $R \& D$ investments, patents per capita and the technology index. ${ }^{99}$

\begin{tabular}{|c|c|c|c|}
\hline Country & $\begin{array}{c}\text { R\&D invest- } \\
\text { ment Rank }\end{array}$ & $\begin{array}{c}\text { Patents per } \\
\text { capita Rank }\end{array}$ & $\begin{array}{c}\text { Technology } \\
\text { index Rank }\end{array}$ \\
\hline Germany & 7 & 10 & 7 \\
\hline Estonia & 15 & 58 & 33 \\
\hline
\end{tabular}

logical Competitiveness of Small European Union Member States. Croatian International Relations Review, 2017, 23(78), pp. 97-126.

98 Organisation for Economic Cooperation and Development. [online]. Available at: https:// stats.oecd.org/\# Accessed: 14.06.2019

99 FLORIDA, Richard, MELLANDER Charlotta, KING, Karen. Global Creativity Index [online]. Available at: http://martinprosperity.org/wp-content/uploads/2011/10/Creativity-and-Prosperity_The-Global-Creativity-Index.pdf Accessed: 14.06.2019 at pg. 40, 41. 
(d) Looking at the Global Innovation Index rankings, one can compare Estonia with Germany on the basis of various indicators. Interestingly, Estonia outperforms Germany in the context of expenditure on education; assessment in reading, mathematics, and science (PISA average scales in reading, mathematics, and science); pupil-teacher ratio; Tertiary enrollment; GERD financed by abroad; and Joint venture/strategic alliance deals. ${ }^{100}$

\begin{tabular}{|c|c|c|}
\hline Indicators & Estonia & Germany \\
\hline Global innovation index & 24 & 9 \\
\hline Expenditure on education & 33 & 56 \\
\hline Government funding per secondary student & 53 & 36 \\
\hline $\begin{array}{l}\text { Assessment in reading, mathematics, and sci- } \\
\text { ence (PISA average scales in reading, mathemat- } \\
\text { ics, and science) }\end{array}$ & 4 & 11 \\
\hline Pupil-teacher ratio, secondary & 10 & 44 \\
\hline $\begin{array}{l}\text { Tertiary enrollment (The ratio of total tertiary } \\
\text { enrollment, regardless of age, to the population } \\
\text { of the age group that officially corresponds to the } \\
\text { tertiary level of education) }\end{array}$ & 21 & 29 \\
\hline $\begin{array}{l}\text { Tertiary level inbound mobility (The number of } \\
\text { students from abroad studying in a given coun- } \\
\text { try, as a percentage of the total tertiary enroll- } \\
\text { ment in that country) }\end{array}$ & 37 & 29 \\
\hline $\begin{array}{l}\text { Researchers (Researchers per million popula- } \\
\text { tion, full-time equivalence) }\end{array}$ & 27 & 13 \\
\hline Gross expenditure on R\&D (GERD) & 25 & 7 \\
\hline $\begin{array}{l}\text { Global R\&D companies, average expenditure top } \\
3 \text { (Average expenditure on R\&D of the top three } \\
\text { global companies) }\end{array}$ & 40 & 2 \\
\hline $\begin{array}{l}\text { QS university ranking average score top } 3 \text { uni- } \\
\text { versities (Sub-pillar 2.3.4 QS university ranking } \\
\text { average score of top } 3 \text { universities) }\end{array}$ & 52 & 11 \\
\hline University/industry research collaboration & 39 & 7 \\
\hline State of cluster development & 68 & 3 \\
\hline $\begin{array}{l}\text { GERD financed by abroad (Percentage of gross } \\
\text { expenditure on R\&D financed by abroad-i.e., } \\
\text { with foreign financing) }\end{array}$ & 38 & 58 \\
\hline Joint venture/strategic alliance deals & 18 & 43 \\
\hline Patent families filed in at least two offices & 27 & 8 \\
\hline $\begin{array}{l}\text { PCT international applications by origin (Num- } \\
\text { ber of international patent applications filed by } \\
\text { residents at the Patent Cooperation Treaty (per } \\
\text { billion PPP\$ GDP)) }\end{array}$ & 28 & 11 \\
\hline
\end{tabular}

100 Global Innovation Index. Analysis. [online]. Available at: https://www.globalinnovationindex.org/analysis-indicator Accessed: 14.06.2019 at pg. 40, 41. 
(e) A comparison of percentage of students in tertiary education enrollment by field in the UNESCO education database shows that Estonia has less students compared to Germany in the fields of Engineering, Manufacturing, Construction, Natural Sciences, Mathematics and Statistics. ${ }^{101}$

\begin{tabular}{|l|l|l|}
\hline Field & Germany & Estonia \\
\hline Engineering, Manufacturing and Construction & 20.73705 & 16.81281 \\
\hline ICT & 6.5359 & 8.16175 \\
\hline Business, Administration and Law & 22.63943 & 22.84506 \\
\hline Natural Sciences, Mathematics and Statistics & 10.23695 & 6.20254 \\
\hline Services & 2.03813 & 5.80717 \\
\hline Arts and Humanities & 13.53735 & 12.65952 \\
\hline Health and Welfare & 7.29796 & 10.8882 \\
\hline Social Sciences, Journalism and Information & 7.76199 & 7.47671 \\
\hline Agriculture, Forestry, Fisheries and Veterinary & 1.50785 & 2.25084 \\
\hline
\end{tabular}

The bases of the German and Estonian education systems are very similar. Even during the Soviet time just a "red" copy of the German education system was in use. However, for the next decades it is extremely important to find back to Bildung. Values play a very important role in the establishment of a fruitful learning-teaching process.

In Estonian education strategy education has been defined as the generator and maintainer of personal cultural and social values. This means that education forms and carries on value attitudes which serve as a basis for personal happiness, cultural sustainability and interoperability of the society. Participation in education facilitates the development of the state and develops the human resources of the society. International comparison of educational indicators and education statistics are the main pillar for the official education policy. The most important international strategies and guidelines are related to the "Europe 2020" Strategy in the framework of which the European Commission has set the targets for the year 2020. The targets in the field of education are the following: at least $95 \%$ of children aged four up to the beginning of the compulsory school age (in Estonia children aged 4-6) should participate in pre-school education, the share of youngsters aged 15 with small functional reading skills, literacy of mathematics and natural sciences should be below 15\% (according to PISA survey), the share of students with low educational level (basic education or below) not participating in education should be less than 10\% (among persons aged 18-24), at least $40 \%$ of persons aged $30-34$ should have attained the tertiary education (higher or vocational secondary education), at least $15 \%$ of adults aged 25-64 should participate in lifelong learning. ${ }^{102}$

101 Unesco. Education. [online]. Available at: http://data.uis.unesco.org/Index. aspx?DataSetCode=EDULIT_DS\&popupcustomise=true\&lang=en\# Accessed: 14.06.2019 102 Statistics Estonia. Education. [online]. Available at: https://www.stat.ee/education 
At the beginning of the academic year 2015/2016, there were 222,000 persons enrolled in formal education in Estonia, with 146,000 of them enrolled in general education, 25,000 in vocational education and 51,000 in higher education. ${ }^{103}$

Here we can see the main difference comparing to Germany, 23\% of persons enrolled in higher education and only $11 \%$ in vocational education. This trend continues then also in the working life, people with higher education are working in positions where actually vocational education is expected.

In the academic year $2017 / 2018$, there were 24,100 vocational education and approximately 46,200 higher education in Estonia. Compared to the previous academic year, the number of students in vocational education decreased by 900 and in higher education by 1600 . The female predominance in higher education has somewhat diminished over the past decade, especially among the graduates. The most popular fields of study were business administration and law (23\%), followed by engineering, production and construction (16\%), and humanities and arts (13\%). ${ }^{104}$

\section{Can Estonia assist its enterprises by utilising the new unitary patent regime?}

(i) Introduction to the Unitary Patent

There is a need felt within Estonia for greater government support for Estonian SMEs and entrepreneurs. Official statistical data shows a shortfall in the number of IPRs held by Estonian entrepreneurs. This also showcases their disinclination towards IPRs in general. In order to rectify this state of affairs, it would be helpful if the Estonian government could subsidise registration of IPR which is generated by RDI related activities of Estonian SMEs. As was shown in the case of Finland, such funding helps to go a long way to make society more innovative. ${ }^{105}$ State aid regulations in EU provide that state funding for obtaining, validating and defending IPRs are eligible costs. ${ }^{106}$

Accessed: 14.06.2019

103 Statistics Estonia. Statistical Yearbook of Estonia. 2016. [online]. Available at: https://www. stat.ee/publication-2016_statistical-yearbook-of-estonia-2016 Accessed: 14.06.2019

104 LEINBOCK, Riina. The Share of Older Students in Vocational and Higher Education is Increasing. [online]. Available at: https://www.stat.ee/aticle-2018-06-21-the-share-of-older-students-in-vocational-and-higher-education-is-increasing Accessed: 14.06.2019

105 DUTT, Pawan, FERRARO, Simona, CHOCHIA, Archil, MULJAR, Ramona. Using Patent Development, Education Policy and Research and Development Expenditure Policy to Understand Differences between Countries: The Case of Estonia and Finland. Baltic Journal of European Studies, 2018, 8(1), pp. 123-153.

106 European Commission. Framework for state aid for research and development and innovation. [online]. Available at: http://ec.europa.eu/competition/state_aid/modernisation/ rdi_framework_en.pdf Accessed: 14.06.2019 
RDI activities give rise to IPRs (such as trade marks, copyrights, patents, designs, geographical indications, etc) which can (and should) be protected both nationally and internationally. This helps in the commercialisation process. The study of the literature associated with Cost Benefit Analysis (CBA) of RDI projects shows that there exist several lacunae in measuring output of RDI.$^{107} \mathrm{In}$ simplistic terms, patents (although not always the most appropriate or practical choice) have emerged as one of the easiest keys to studying and analysing RDI output in many fields. Further, as stated above, compared to domestically filed patents, it has been observed that patents filed abroad can offer significant indications of a business (and licensing) strategy which covers export markets. Basberg ${ }^{108}$ and Gaetan de Rassenfosse and Potterie ${ }^{109}$ state that foreign patents (such as triadic patents) also serve to be good indicators of technology as they are of higher quality than domestically filed patents, are more expensive to obtain and are also expected to be much more profitable.

Leaving aside other forms of IPR, if one were to study how can international patents be cost effectively subsidised by the RDI support strategies for SMEs of small EU member states such as Estonia then there arises the need to focus on which type of international patent scheme is appropriate. While a robust international patent policy is imperative, it would not be realistic to expect the Estonian government to subsidise all types of international patents due to the prohibitive costs involved.

(ii) Strategies for international patent routes at present

Dechezleprêtre, Ménière and Mohnen ${ }^{110}$ have researched on the various ways to apply for multiple patents for the same invention in different parts of the world. They have concluded that it is possible since there exist national, regional and international patent systems. The various options are as follows:

Under the Paris Convention, a patent applicant in one country can file within a year in other convention countries. This is extremely expensive since the entire application - translation - search - examination process has to be repeated in each country and the corresponding fees also have to be paid.

107 European Commission. Guide to Cost-Benefit Analysis of Investment Projects Economic appraisal tool for Cohesion Policy 2014-2020. [online]. Available at: https://ec.europa.eu/ regional_policy/sources/docgener/studies/pdf/cba_guide.pdf Accessed: 14.06.2019

108 BASBERG, Bjørn. Patents and the measurement of technological change: a survey of the literature. Research Policy, 1987, 16 (2-4), pp. 131-141 at 136.

109 DE RASSENFOSSE, Gaetan, VAN POTTELSBERGHE DE LA POTTERIE, Bruno. A policy insight into the R\&D-patent relationship. Research Policy, 2009, vol. 38, pp, 779-792 at 782 .

110 DECHEZLEPRETRE, Antoine, MENIERE, Yann, MOHNEN, Myra. International Patent Families: From Application Strategies to Statistical Indicators. Scientometrics, 2017, vol. 111(2), pp. 793-828. 
Another option is to file an international patent application under the Patent Cooperation Treaty (PCT). This is not an international patent as such but rather gives a period of 30 months to file national applications in other PCT countries. The written opinion on patentability is issued by the International Searching Authority which is generally accepted by all other patent offices, thereby saving costs and making matters transparent. However, national phase entry costs are still to be borne in individual countries of choice and include translation and administrative costs.

An alternative route is to file a European patent application under the European Patent Convention. If successful, a European patent is granted by the EPO which gives the right to the applicant to obtain national patents in designated countries. No additional examinations are required, however national fees have to be paid for each member state application and translation costs can be very high.

Triadic patents are patents which are applied in USA, EPO and Japan simultaneously. Such patents would require paying official filing fees in the US, Japanese and European Patent offices, along with separate administrative fees, processing fees, legal fees, etc. Greenspon and Rodigues estimate that the total costs for obtaining a triadic patent could range between approximately 5,000 to 15,000 Euros based upon the type and how complex the invention is. ${ }^{111}$

It should be noted that post registration, renewal or maintenance fees also have to be paid in each country for a maximum of upto 20 years from date of application and these are often to the tune of thousands of Euros.

(iii) Analysis of the usefulness and effectiveness of the newly introduced unitary patent in view of the above findings

Therefore, from the above it can be seen that applying for and pursuing international patent applications can be an expensive affair. Since Estonia is in the EU, the authors are of the view that the Estonian government should focus more upon helping Estonian SMEs and entrepreneurs to expand their international IPR especially patent portfolios by investing in the recently introduced UP under Regulation (EU) No 1257/2012.

There is an abundance of literature which outlines the costs and benefits of the newly developed UP system in Europe. A UP enables an applicant to make a single request for patent protection in 26 EU Member States (All the EU Member States except Spain and Croatia are participating in enhanced cooperation in the area of the creation of Unitary Patent protection). Such a UP would provide uniform patent protection in the above-mentioned EU Member States, thereby allowing considerable savings. Its effectiveness lies in the fact that whereas today

111 GREENSPON, Jacob, RODIGUES, Erika. Are Trends in Patenting Reflective of Innovative Activity in Canada? [online]. Available at: http://www.csls.ca/reports/csls2017-02.pdf Accessed: 14.06.2019 
inventors can seek protection for their inventions in Europe through the national patent or European patent with a centralised patent examination process (conducted by the EPO), there is nonetheless a need for the granted European patents to undergo validation and to be maintained individually in each country in order for them to take effect. Validation procedures are different in different countries and entail huge costs (including translation costs, fees for validation, attorney fees and also renewal costs). Under the UP scheme, renewals will be under one procedure and will utlise the same currency and will be subject to the same deadlines. Costs will be further reduced due to the EPO handling all post grant administration tasks. More importantly, the renewal fees have been positioned at extremely competitive levels when compared globally. And last but not the least is the envisaged role for the Unified Patent Court (UPC). ${ }^{112}$

The UP is expected by the EPO to enter into force in the beginning of 2019. Cost savings are estimated to be substantial. For example, the annual fees for maintaining a UP for 20 years will be Euros 35,555 while based on national renewal fees as at 1 January 2017, the annual fees for maintaining national patents individually in each of the 26 member states would be Euros 169,667. Notwithstanding other associated costs (such as attorney fees, translations charges, etc), a UP in 26 member states will be less expensive than a European Patent presently in force in 4 of the member states (usually patents are preferred by applicants in mostly Germany, France, UK and Italy, while the other member states are generally ignored as their markets are not considered to be very economically remunerative for patenting purposes). ${ }^{113}$

In their seminal work on the CBA of the UP, Danguy and van Pottelsberghe de la Potterie have conducted a thorough review of the existing patent process in the EU. They have observed that the patent system in Europe is fragmented, being the sum of the 27 different patent systems which are found in the various Member States. They have stated that patents in the EU normally tend to be enforced in only 6 major EU Member States. Such patents tend to be four times costlier than corresponding patents filed in other large economies. Further, due to translation costs and renewal fees, a patent protection for inventions in many EU member states can be almost 15 times more expensive than in the US. Such wide cost variances not only lower the demand for patenting in Europe, but they also have an adverse effect on SMEs which want to access the patent system. ${ }^{114}$

112 European Patent Office. Unitary Patent Guide. Obtaining, maintaining and managing Unitary Patents. [online]. Available at: http://documents.epo.org/projects/babylon/eponet. nsf/0/C3ED1E790D5E75E0C125818000325A9B/\$File/Unitary_Patent_guide_en.pdf Accessed: 14.06.2019

113 European Patent Office. Cost of a Unitary Patent. [online]. Available at: https://www.epo. org/law-practice/unitary/unitary-patent/cost.html Accessed: 14.06.2019

114 DANGUY, Jerome, VAN POTTELSBERGE DE LA POTTERIE, Bruno. Cost-Benefit Analysis of the Community Patent. Journal of Benefit-Cost Analysis, 2011, vol. 2 (2), pp. $1-43$ at 1 . 
Harhoff has focused on the CBA of the unified and integrated European patent litigation system. His findings have shown that the European economy can benefit a lot if court cases dealing with infringement and revocation of patents are not duplicated. These findings have special implications for the SMEs and entrepreneurs of small Member States such as Estonia. He has drawn attention to research conducted in USA which has cast light on the extremely high marginal costs which are incurred by SMEs for protecting their patents (when compared with larger firms). In certain high-tech sectors, due to high patent litigation SMEs often avoid seeking patents. This must be considered by the EPO in order to safeguard SMEs. Research has shown that patent litigation cases in Central and Eastern European Countries in general and Estonia in particular are negligible, when compared with Western Europe. Again, when to see from the viewpoint of SMEs in Estonia, litigation costs are a key parameter which affect litigation behaviour, out of court settlements and strategic long term planning with regard to patents. Thus, the need arises for low cost systems. In this regard the proposed UPC would help SMEs to save money due to avoidance of duplication in patent litigation and overall reduction in costs. ${ }^{115}$

Danguy and van Pottelsberghe de la Potterie are of the opinion that the UP together with the unified European and EU Patents Court system would be a game changer due to their ability to make patenting cheaper, attractive and effective. In this quest, the above researchers have studied the consequences of the UP on: the incomes for the EPO and national patent offices, the implications for applicants in terms of incurred fees, and the direct impact on major actors in the patent system. They conclude that the current fragmented patent system in Europe has 2 types of failures being firstly the extremely high costs due to the combined renewal fees which must be paid by patentees in each Member State and secondly the uncertainties arising from national jurisdiction ultimately deciding whether to grant or invalidate a patent and the risk of simultaneous parallel litigation. It is estimated that the UP would abolish both these failings. On a per capita basis, thanks to the size of Europe's 500 million inhabitants, protecting a UP for 10 years is estimated to cost approximately 23 Euros per million capita in the whole EU. (Please note that at present a patent costs 76 Euros per million capita in 13 of the richest EU Member States). In contrast, 1 patent for 10 years costs 28 Euros in Japan and 12 Euros in USA per million capita. Therefore the UP can be seen as being extremely effective. This decrease in patent prices is hoped to spur a growth in the demand for patents in the EPO. The UP with a unified jurisdiction will bring down costs and uncertainty while maintaining high quality standards in the EPO examination process. This accrued benefit will help SMEs and universities to more easily access the patent system in Europe and

115 HARHOFF, Dietmar. Economic Cost-Benefit Analysis of a Unified and Integrated European Patent Litigation System. [online]. Available at: https://www.researchgate.net/publication/267839173_Economic_Cost-Benefit_Analysis_of_a_Unified_and_Integrated_European_Patent_Litigation_System Accessed: 14.06.2019 
also make the European market more attractive for companies both locally and from abroad. ${ }^{116}$

Further, research by Haroff has shown that by offering the potential for resolving patent related legal conflicts across the entire EU, there will be a huge Social Cost Benefit. Firstly, demand for patent litigation will generally reduce since the UPC will stamp down on divergent expectations and asymmetric information. This will result in increased private negotiations and settlements between parties, based on homogeneous expectations. Secondly, these cost benefits will lead to an increase in the number of European Patents being applied for and granted in member states such as Estonia where firms (especially SMEs) are not particularly active in terms of holding huge patent portfolios. This can be considered as being reflective of economic growth in Estonia. Such growth (especially in high tech areas) will in turn create demand for a patent litigation system which is efficient and cost effective (which the UPC will provide). Thirdly, SMEs in countries such as Estonia will not have to use expensive and cumbersome national courts for litigation and resolution of patent disputes. ${ }^{117}$

It is estimated by Danguy and van Pottelsberghe de la Potterie that the UP would help the business sector in Europe to save over 250 million Euros. But since these are estimates based on an econometric model, one must not ignore the complex factors that go into budgetary planning in this field. For instance, the impact of BREXIT on the UP is as as yet undetermined, given that English is one of the 3 key languages of the UP and the court is proposed to be established in London. They have shown that the UP would make the European patent system much simpler. This would in turn attract companies from within and outside the EU and also suitably affect SMEs and universities in EU. This would undoubtedly benefit businesses generally and high technology start ups and entrepreneurships particularly, leading to a positive social CBA. ${ }^{118}$

Since SMEs in member states like Estonia cannot usually afford to fight costly patent litigation cases in court, they are therefore particularly vulnerable to suffer from economic uncertainties. For such SMEs, the UP and the UPC will be very helpful. Further, if Member States like Estonia can successfully lobby for more amenities such as fast track legal proceedings or lower fees for their SMEs,

116 DANGUY, Jerome, VAN POTTELSBERGE DE LA POTTERIE, Bruno. Cost-Benefit Analysis of the Community Patent. Journal of Benefit-Cost Analysis, 2011, vol. 2 (2), pp. $1-43$.

117 HARHOFF, Dietmar. Economic Cost-Benefit Analysis of a Unified and Integrated European Patent Litigation System. [online]. Available at: https://www.researchgate.net/publication/267839173_Economic_Cost-Benefit_Analysis_of_a_Unified_and_Integrated_European_Patent_Litigation_System Accessed: 14.06.2019 at p. 44 .

118 DANGUY, Jerome, VAN POTTELSBERGE DE LA POTTERIE, Bruno. Cost-Benefit Analysis of the Community Patent. Journal of Benefit-Cost Analysis, 2011, vol. 2 (2), pp. $1-43$ at 29,30 . 
then it would be highly beneficial for the rapidly growing high-tech firms in these member states. ${ }^{119}$

An outline of the pros and cons of the UP are as follows. The benefits are a reduction in costs (by some estimates upto 80 percent of administrative costs), simplified and shortened procedures and a UPC which is expected to reduce case costs, decrease contradictory decisions and increase legal certainty. The weaknesses of the UP are that it reduces choice for patentees (they can either pay for full protection in all Member States or lose all rights), an increase in the possibilities of patent trolls and bifurcation (ie., the separation of powers when it comes to dealing with patent infringement and/or validity), forum shopping, an exponential increase in the number of new filings for patent applications at the EPO which would swamp it, etc. ${ }^{120}$ To add to the above are uncertainties raised by recent political events such as BREXIT. ${ }^{121}$

However, there are no doubts that if properly implemented, the UP can greatly increase the potential for marketing of the patented goods and can provide for increased licensing opportunities. If implemented across the EU, it would allow for innovating at scale across the length and breath of the EU. Thus owning UPs would improve the balance sheets of the patent owners and also raise the valuation of their held assets. This would result in allowing them to get access to more funding, thereby allowing more possibilities for R\&D opportunities. In short, the rosy outlook of cheaper patent protection across the EU entails that small innovators would find growth space much more easily. This system would also entice UP owners from outside the EU to invest more in R\&D and towards increasing manufacturing and selling of their goods in the EU. ${ }^{122}$

(iv) Unitary patent in the context of social systems theory and the $4 \mathrm{~S}$ Framework

A brief review of the available strategies for international patent routes, as listed above, shows that the following options are available, namely priority filing under the Paris Convention, PCT route, European patent, triadic patent or the UP. The literature review shows that the UP is the most cost effective route. Each of these options can be legally subsidised by the Estonian government under the

119 HARHOFF, Dietmar. Economic Cost-Benefit Analysis of a Unified and Integrated European Patent Litigation System. [online]. Available at: https://www.researchgate.net/publication/267839173_Economic_Cost-Benefit_Analysis_of_a_Unified_and_Integrated_European_Patent_Litigation_System Accessed: 14.06.2019 at p. 51 .

120 GLAZER, Klara. Advantages and Disadvantages of the Single European Patent. Naše gospodarstvo/Our economy, 2015, vol. 61 (2), pp. 24-34.

121 MCDONAGH, Luke. European Patent Litigation in the Shadow of the Unified Patent Court. Cheltenham: Edward Elgard Publishing, 2016, pp. 1-9.

122 BIS - Intellectual Property Office and Ministry of Justice. Unified Patent Court Implementation - Unitary Patent. [online]. Available at: https://assets.publishing.service.gov.uk/government/uploads/system/uploads/attachment_data/file/492093/Final_Stage_IA_-_Unified_Patent_Court_Implementation_-_Unitary_Patent.pdf Accessed: 14.06.2019 
state aid rules, RDI framework and GBER which allow for substantial sums of government aid with respect to protection of IPR generated through RDI activities of SMEs.

Interestingly, as per the table below, when one looks at the UP regime through the Social System theory and the 4S framework comprising of Skills, Social Networking, Scope and Scale, then it is apparent that the encouragement for obtaining UP (through subsidisation) can be extremely helpful for Estonian society in the long run as follows:

The four capitals and relevant UP attributes

\begin{tabular}{|c|c|}
\hline Capital & $\begin{array}{c}\text { UP Attributes } \\
\text { Culture }\end{array}$ \\
$\begin{array}{c}\text { Increased European standard of educa- } \\
\text { tion regarding patentability, } \\
\text { Improved awareness of IPR at EU level, } \\
\text { Focus on commercialisation and efficiency, } \\
\text { Breaking of barriers between east and west }\end{array}$ \\
$\begin{array}{c}\text { Cost effective, } \\
\text { Opens EU market for innovative products, } \\
\text { Simpler UP system, } \\
\text { UPC benefits business, } \\
\text { Economic }\end{array}$ \\
$\begin{array}{c}\text { Freedom from expensive and cumbersome national } \\
\text { courts by development of a centralised patent litigation } \\
\text { system at EU level which is efficient and cost effective, } \\
\text { Reduction in administrative costs } \\
\text { A simplified and shortened procedure along with } \\
\text { UPC which is expected to reduce litigation costs } \\
\text { Innovation possible at scale } \\
\text { Raises value of IPR assets held by SMEs } \\
\text { EU wide networking, } \\
\text { Creation of support eco-system, } \\
\text { Increased private negotiations and set- } \\
\text { tlements between actors }\end{array}$ \\
\hline
\end{tabular}




\begin{tabular}{|c|c|}
\hline Strategic & $\begin{array}{c}\text { Cost effective, } \\
\text { Development of EU networking strat- } \\
\text { egy at corporate level by SMEs, } \\
\text { Increase in the number of European Pat- } \\
\text { ents held by Estonian SMEs, } \\
\text { European patent system much sim- } \\
\text { pler thereby benefiting businesses, } \\
\text { Increases legal certainty, } \\
\text { Improves possibility of licensing inventions all across EU }\end{array}$ \\
\hline
\end{tabular}

In view of the above, the authors state that the Estonian Government should focus on the possibilities emerging thanks to the new UP regime. State aid policies in respect of international IPR generated through RDI should be designed to encourage Estonian SMEs to pursue UPs as the first step towards international patent portfolios.

\section{Recommendations and conclusions}

The goal of this paper is not merely to outline the differences between Estonia and Germany in regard to the number of triadic patents, the tertiary education level mainly, the gross domestic expenditure on R\&D as a percentage of GDP and the expenditure for total $\mathrm{R} \& \mathrm{D}$ personnel and for personnel researchers. Instead, the aim is to provide recommendations to Estonia for adoption of best practices in the field of RDI and making suitable changes (where required) to the government policies based on the German experiences. In light of the above discussion, some recommendations for Estonia are as follows:

(i) A central role for the Estonian Research Council (ETAG) for the purposes of commercial exploitation of RDI resulting from innovation processes of universities and their spinoffs/ startups (which are collaborations between Estonian research institutes and private enterprises). A key change to state funding regulations should be the requirement that all projects should have clear cut plans for exploitation of RDI output which need to be implemented. The inventions of Estonian universities should be patented internationally in the names of the respective universities but the sole and exclusive licenses to commercially exploit such patented inventions should be held by ETAG which should have the power to further sub license the patents. The inventions would be owned by the employer (the university) and the university researcher would receive 30 percent of the gross income. The revenues generated by ETAG through the formation of patent pools should be ploughed back into the system by making more funds available to support researchers who wish to set up their own startups. A favourable environment for startups should also be created by ETAG providing for centralised mentorship programs, awards for entrepreneurs and by setting up pro- 
fessorial chairs in entrepreneurship studies in higher educational institutions. A revenue sharing model should be adopted between ETAG and Estonian universities so that the profits from RDI output are shared equitably. This centralisation will help individual universities in Estonia which lack adequate resources for IP protection and exploitation. In order to patent inventions internationally, ETAG should be initially supported financially (for a period of 5 years) by the Estonian state and through EU funded programs. For the purposes of exploitation of RDI, a special patent and exploitation department (manned by experienced professionals in this field) should be set up in ETAG in order to enable patenting and exploitation of inventions created by Estonian universities.

(ii) There is a need for diversification of science education, whereby not only RDI activities but the management and commercialisation of IP should be stressed upon at all levels from junior researchers upto professors.

(iii) ETAG should focus on key areas for development since resources are scare. There should be more transparency and competition in encouraging, selecting and promoting start up activities.

(iv) Increase in government expenditure on RDI activities, encouragement of private expenditure in RDI by offering tax incentives (such as a tax holiday for 5 years, provision to set off losses against profits earned in the future, etc), establishing and supporting high technology departments in public universities and research centres, and the promotion of careers and job opportunities in the fields of science and technology. ${ }^{123}$

(v) Studies indicate a linkage between regions of high RDI activities and presence of headquarters of large (and very often multinational) enterprises. This suggests a correlation between ownership and RDI activities. ${ }^{124}$ Hence, Estonia should try to attract multinational companies who wish to set up their headquarters within Estonia by offering tax incentives.

(vi) Countries like Estonia have very small economies and mostly trade in goods. Small EU member states such as Estonia and also medium EU member states need to shift focus towards high technology services and new areas of ICT and software applications. Therefore, Estonia and similar EU countries should adopt a more coordinated approach when it comes to influencing researchers and their productivity vis a vis propensity to patent, especially in high technology areas. Estonia should focus on international patents as a measurable output for RDI. Already in universities like TalTech, patents are given equal importance as high $\mathrm{h}$ index published articles (1.1) when it comes to election of Science Professors. Estonian universities and RDI institutions should emphasise on fil-

123 COZZA, Claudio, SCHETTINO, Francesco. Explaining the Patenting Propensity: A Regional Analysis Using EPO-OECD Data. [online]. Available at: https://mpra.ub.unimuenchen.de/45084/ Accessed: 14.06.2019 at pg. 11.

$124 \mathrm{Ibid}$ at pg. 12. 
ing UPs. Once UPs are recognised as the defacto standard within Estonia, the next step is to push for triadic patent filings. This will also influence behaviour of entrepreneurs, especially in the field of university spin offs.

(vii) In view of the high costs incurred to acquire international patents (especially triadic patents), the Estonian government should look towards ways to reduce the cost burden on their companies (especially start ups). The EPO runs various schemes (for example COSME) whereby SMEs are eligible for financial support (or refund of certian fees) (Europa Easme, 2018). Estonia is not yet a member of such support schemes. If the EPO refunds $50 \%$ of the official filing fees professional fees, etc, of selected patent applications then Estonia can refund an additional $25 \%$. By doing so, Estonia can substantially reduce the burden of patent expenses on Estonian SME applicants at lower costs to itself. Which is why there is also need for proper institutional support. For this pre-existing institutions within Estonia should be earmarked with clear responsibilities.

(viii) Government support in development of IPRs by offering tax credits or deductions for obtaining UPs. Tax measures can be used for reducing the following: patenting costs, costs for acquisition of patents, costs for acquiring license rights and taxes on royalties earned from licensing of patents. There should be grants or subsidies for obtaining UPs either when they apply for a patent for the first time or for multiple patent applications by the same SME on a case-bycase basis. Similarly, subsidised loans and loan guarantees should be provided for obtaining Ups. There should be a provision for lower official fees or refund of official fees for Ups. In many countries within and outside EU, patent application and maintenance costs are reduced for SMEs. The fees for the UP are proposed to be shared between the EPO and the Estonian Patent Office. So one suggestion is that Estonia can decide that from the above share received by the Estonian Patent Office, a small sum can be refunded back to the Estonian SME UP applicant.

(ix) Estonia should lobby to EPO for making licensing of UPs easier and more cost effective by providing for standardised agreements and cash incentives. Estonia should also make obtaining UPs a mandatory or preferred outcome for EU funded science projects under post - H2020.

In conclusion we can see that the $4 \mathrm{~S}$ framework theoretical model whereby entrepreneurs strive for goal attainment by developing novel action patterns within the framework of existing patterns of behaviour which are shared within a cultural context is important for wholesome development of Estonian society. To make the Estonian economy knowledge-driven and technologically intensive, the state must focus on cultural, economic, social and strategic factors. Education, collaboration, coordination and grants are the way forward. 


\section{References}

ALLEN, Mathew. Germany's National Innovation System. In Encyclopaedia of Technology and Innovation. Oxford: Basil Blackwell, 2009, pp. 375-389.

BAILY, Martin, BOSWORTH, Barry. US Manufacturing: Understanding Its Past and Its Potential Future. Journal of Economic Perspectives, American Economic Association, 2014 , vol. 28 , no. 1 , pp. 3-26

BANERJEE, Supriya, WAHL, Mike, PANIGRAHI, Jayant. Technology, innovation and knowledge transfer: A value chain perspective. International Journal of Mechanical Engineering and Technology (IJMET), 2018, vol. 9 (1), pp. 1145-1161.

BASBERG, Bjørn. Patents and the measurement of technological change: a survey of the literature. Research Policy, 1987, 16 (2-4), pp. 131-141 at 132.

BIS - Intellectual Property Office and Ministry of Justice. Unified Patent Court Implementation - Unitary Patent. [online]. Available at: https://assets.publishing.service.gov. uk/government/uploads/system/uploads/attachment_data/file/492093/Final_Stage_ IA_-_Unified_Patent_Court_Implementation_-_Unitary_Patent.pdf Accessed: 14.06.2019

BLIND, Knut, EDLER, Jakob, FRIETSCH, Rainer, SCHMOCH, Ulrich. Motives to patent: Empirical evidence from Germany. Research Policy, 2006, 35, pp. 655-672.

CARLILE, Paul. A Pragmatic View of Knowledge and Boundaries. Organization Science, 2002, 13(4), pp. 442-455.

CARLILE, Paul. Transferring, Translating, and Transforming: An Integrative Framework for Managing Knowledge Across Boundaries. Organization Science, 2004, 15(5), pp. $555-568$.

COZZA, Claudio, SCHETTINO, Francesco. Explaining the Patenting Propensity: A Regional Analysis Using EPO-OECD Data. [online]. Available at: https://mpra. ub.uni-muenchen.de/45084/ Accessed: 14.06.2019

DANGUY, Jerome, VAN POTTELSBERGE DE LA POTTERIE, Bruno. Cost-Benefit Analysis of the Community Patent. Journal of Benefit-Cost Analysis, 2011, vol. 2 (2), pp. $1-43$

DE RASSENFOSSE, Gaetan, VAN POTTELSBERGHE DE LA POTTERIE, Bruno. A policy insight into the R\&D-patent relationship. Research Policy, 2009, vol. 38, pp, 779-792.

DECHEZLEPRETRE, Antoine, MENIERE, Yann, MOHNEN, Myra. International Patent Families: From Application Strategies to Statistical Indicators. Scientometrics, 2017, vol. 111(2), pp. 793-828.

DUBNER, Stephen. What Are the Secrets of the German Economy - and Should We Steal Them? [online]. Available at: http://freakonomics.com/podcast/secrets-germaneconomy-steal/ Accessed: 14.06.2019

DUTT, Pawan, FERRARO, Simona, CHOCHIA, Archil, MULJAR, Ramona. Using Patent Development, Education Policy and Research and Development Expenditure Policy to Understand Differences between Countries: The Case of Estonia and Finland. Baltic Journal of European Studies, 2018, 8(1), pp. 123-153.

Estonian Patent Office. Establishment of the Estonian Patent Office. [online]. Available at: https://www.epa.ee/en/patent-office/establishment-estonian-patent-office Accessed: 14.06.2019

EUGSTER, Esprit. Evolution and Enforcement of Intellectual Property Law in Russia. Washington University Global Studies Law Review, 2010, vol. 9, issue 1, pp. 131-151.

European Commission. Council Recommendation on the 2019 National Reform Pro- 
gramme of Estonia and delivering a Council opinion on the 2019 Stability Programme of Estonia. [online]. Available at: https://eur-lex.europa.eu/legal-content/EN/TXT/?q $\mathrm{id}=1560258145940$ \&uri=CELEX\%3A52019DC0506 Accessed: 14.06 .2019

European Commission. Europe 2020 Strategy. [online]. Available at: https://ec.europa.eu/ info/business-economy-euro/economic-and-fiscal-policy-coordination/eu-economic-governance-monitoring-prevention-correction/european-semester/framework/ europe-2020-strategy_en Accessed: 14.06.2019

European Commission. Framework for state aid for research and development and innovation. [online]. Available at: http://ec.europa.eu/competition/state_aid/modernisation/rdi_framework_en.pdf Accessed: 14.06.2019

European Commission. Guide to Cost-Benefit Analysis of Investment Projects Economic appraisal tool for Cohesion Policy 2014-2020. [online]. Available at: https://ec.europa. eu/regional_policy/sources/docgener/studies/pdf/cba_guide.pdf Accessed: 14.06.2019

European Patent Office. Cost of a Unitary Patent. [online]. Available at: https://www.epo. org/law-practice/unitary/unitary-patent/cost.html Accessed: 14.06.2019

European Patent Office. Patents and the Fourth Industrial Revolution. [online]. Available at: http://documents.epo.org/projects/babylon/eponet.nsf/0/17FDB5538E87B4B9 C12581EF0045762F/\$FILE/fourth_industrial_revolution_2017_en.pdf Accessed: 14.06.2019

European Patent Office. Unitary Patent Guide. Obtaining, maintaining and managing Unitary Patents. [online]. Available at: http://documents.epo.org/projects/babylon/ eponet.nsf/0/C3ED1E790D5E75E0C125818000325A9B/\$File/Unitary_Patent_ guide_en.pdf Accessed: 14.06.2019

Eurostat. National accounts and GDP. [online]. Available at: https://ec.europa.eu/eurostat/statistics-explained/index.php/National_accounts_and_GDP\#Developments_ in_GDP_in_the_EU:_growth_since_2013 Accessed: 14.06.2019

EVAS, Tatjana, HOFFMANN, Thomas, JOAMETS, Kristi, KERIKMAE, Tanel, LOIK, Ramon, NYMAN-METCALF, Katrin, POPOV, Aleksandr, SARAV, Sandra. General Frameworks. In KERIKMAE, Tanel, JOAMETS, Kristi, RODINA, Anita, PLEPS, Janis, GRUODYTE, Edita (eds). The Law of the Baltic States, Springer Verlag, 2018, pp. $41-100$.

FERRARO, Simona, DUTT, Pawan, KERIKMAE, Tanel. Using Patent Development, Education Policy and Research and Development Expenditure Policy to Increase Technological Competitiveness of Small European Union Member States. Croatian International Relations Review, 2017, 23(78), pp. 97-126.

FLORIDA, Richard, MELLANDER Charlotta, KING, Karen. Global Creativity Index [online]. Available at: http://martinprosperity.org/wp-content/uploads/2011/10/Creativity-and-Prosperity_The-Global-Creativity-Index.pdf Accessed: 14.06.2019

FLORIO, Massimo, FORTE, Stefano, PANCOTTI, Chiara, SIRTORI, Emanuela, VIGNETTI, Silvia. Exploring Cost Benefit Analysis of Research, Development and Innovation Infrastructures: An Evaluation Framework. [online]. Available at: https:// arxiv.org/ftp/arxiv/papers/1603/1603.03654.pdf Accessed: 14.06.2019

German Patent and Trade Mark Office. 140 years of the patent office in Germany. [online]. Available at: https://www.dpma.de/english/our_office/about_us/history/140yearsoft hepatentoffice/index.html Accessed: 14.06.2019

GLAZER, Klara. Advantages and Disadvantages of the Single European Patent. Naše gospodarstvo/Our economy, 2015, vol. 61 (2), pp. 24-34. 
Global Innovation Index. Analysis. [online]. Available at: https://www.globalinnovationindex.org/analysis-indicator Accessed: 14.06.2019

GREENSPON, Jacob, RODIGUES, Erika. Are Trends in Patenting Reflective of Innovative Activity in Canada? [online]. Available at: http://www.csls.ca/reports/csls2017-02.pdf Accessed: 14.06.2019

GROEN, Aard, De WEERD-NEDERHOF, Petra, KERSSENS-VAN DRONGELEN, Inge, BADOUX, Rob, OLTHUIS, Gerard. Creating and Justifying Research and Development Value: Scope, Scale, Skill and Social Networking of R\&D. Creativity and Innovation Management, 2002, vol. 11, no. 1, pp. 2-16.

GROEN, Aaard. Knowledge Intensive Entrepreneurship in Networks: Towards a Multilevel/Multi Dimensional Approach. Journal of Enterprising Culture, 2005, vol. 13 (1), pp. 69-88.

GUNNAR, Hedlund. A Model of Knowledge Management and the N-Form Corporation. Strategic Management Journal, 1994, vol 15 (S2), pp. 73-90.

HALL, Peter, SOSKICE, David. Varieties of Capitalism: The Institutional Foundations of Comparative Advantage. Oxford University Press; 2001.

HARHOFF, Dietmar. Economic Cost-Benefit Analysis of a Unified and Integrated European Patent Litigation System. [online]. Available at: https://www.researchgate.net/ publication/267839173_Economic_Cost-Benefit_Analysis_of_a_Unified_and_Integrated_European_Patent_Litigation_System Accessed: 14.06.2019

International Monetary Fund. Datasets GDP Current Prices. [online]. Available at: https:// www.imf.org/external/datamapper/NGDPD@WEO/OEMDC/ADVEC/WEOWORLD/EU/EUQ Accessed: 14.06.2019

KIRWAN, Paul, VAN DER SIJDE, Peter, GROEN, Aard. Early-Stage Networking: How Entrepreneurs Use Their Social Capital to Establish and Develop High-Technology Start-Ups. In J. Ulijn, D. Drillon, \& F. Lasch (Eds.), Entrepreneurship, Cooperation and the Firm: The Emergence and Survival of High-Technology Ventures in Europe. Edward Elgar Publishing, 2007, pp. 391-414.

KWON, Aoonwoo, LEE, Jihong, LEE, Sokbae. International Trends in Technological Progress: Evidence from Patent Citations, 1980-2011. The Economic Journal, 2017, vol. 127, issue 605, pp. F50-F70.

LEINBOCK, Riina. The Share of Older Students in Vocational and Higher Education is Increasing. [online]. Available at: https://www.stat.ee/aticle-2018-06-21-the-shareof-older-students-in-vocational-and-higher-education-is-increasing Accessed: 14.06.2019

LELOUX, Mirjam, GROEN, Aard. Estimating Business Value of Academic Research Outcomes: Towards a Multi-Dimensional Approach. International Journal of Technology Transfer and Commercialisation, 2009, vol. 8(1), pp. 3-21.

MARIN, Dalia. Inequality in Germany: How it differs from the US. [online]. Available at: https://voxeu.org/article/inequality-germany-how-it-differs-us Accessed: 14.06.2019

MCDONAGH, Luke. European Patent Litigation in the Shadow of the Unified Patent Court. Cheltenham: Edward Elgard Publishing, 2016, pp. 1-9.

Ministry of Education and Research. Estonian Research and Development and Innovation Strategy 2014-2020 "Knowledge-based Estonia". [online]. Available at: https://www. hm.ee/sites/default/files/estonian_rdi_strategy_2014-2020.pdf Accessed: 14.06.2019

NAUDE, Wim, NAGLER, Paula, Technological Innovation and Inclusive Growth in Germany. IZA Discussion Paper, 2017, No. 11194, pp. 1-53.

NICKERSON, Jackson, YEN, James, MAHONEY, Joseph. Exploring the Problem-Find- 
ing and Problem-Solving Approach for Designing Organizations. Academy of Management Perspectives, 2012, vol. 26 no. 1, pp. 52-72.

NONAKA, Ikujiro, TOYAMA, Ryoko, KONNO, Noboru. SECI, $B a$ and Leadership: a Unified Model of Dynamic Knowledge Creation. Long Range Planning, 2000, vol. 33(1), pp. 5-34.

Organisation for Economic Cooperation and Development. [online]. Available at: https:// stats.oecd.org/\# Accessed: 14.06.2019

PARSONS, Talcott. The Social System. London: Routledge \& Kegan Paul Ltd., 1951.

PLANTERA, Federico. SmartCap - Investing local, thinking global. Interview with Sille Pettai. [online]. Available at: https://www.startupestonia.ee/blog/smartcap-investinglocal-thinking-global-interview-with-sille-pettai Accessed: 14.06.2019

SAP. Production of the future: How to Prepare for the Fourth Industrial Revolution. Walldorf: SAP. 2013.

SANSO-NAVARRO, Marcos, VERA-CABELLO María. The long-run relationship between R\&D and regional knowledge: the case of France, Germany, Italy and Spain. Regional Studies, 2018, 52:5, pp 619-631.

SCHIERMEIER, Quirin. How Estonia Blazed a Trail in Science. [online]. Available at: https://www.nature.com/articles/d41586-019-00209-7?fbclid=IwAR3Pzwg_gjnmPRcVSA9HcFgE7I3KgZ61SaoqLtJLOlqPhL67OmuPdFroUlM Accessed: 14.06.2019

SCHWARTZ, Shalom. An Overview of the Schwartz Theory of Basic Values. Online Readings in Psychology and Culture, 2012, 2(1).

Statistics Estonia. Education. [online]. Available at: https://www.stat.ee/education Accessed: 14.06.2019

Statistics Estonia. Statistical Yearbook of Estonia. 2016. [online]. Available at: https://www. stat.ee/publication-2016_statistical-yearbook-of-estonia-2016 Accessed: 14.06.2019

TEECE, David, PISANO, Gary, SHUEN, Amy. Dynamic Capabilities and Strategic Management. Strategic Management Journal, 1997, vol. 18, pp. 509-533.

Unesco. Education. [online]. Available at: http://data.uis.unesco.org/Index. aspx?DataSetCode=EDULIT_DS\&popupcustomise=true\&lang=en \# Accessed: 14.06.2019

VAN DER VEEN, Marijke, WAKKEE, Ingrid. Understanding the entrepreneurial process. In WATKINS, David (ed.) Annual Review of Progress in Entrepreneurship Research. Brussels: European Foundation for Management Development, 2004, pp. 114-152.

WAHL, Mike. Strategic Factor Analysis for Industry 4.0. Journal of Security and Sustainability Issues, 2015. Vol 5, no. 2, pp 241-247.

WHYTE, Andrew. Academic unions call one-hour strike for June 5. [online]. Available at: https://news.err.ee/946791/academic-unions-call-one-hour-strike-for-june-5 Accessed: 14.06.2019

World Economic Forum. Germany is the world's most innovative economy. [online]. Available at: https://www.weforum.org/agenda/2018/10/germany-is-the-worlds-mostinnovative-economy/ Accessed: 14.06.2019

ZETTERBERG, Hans. The Study of Values. In SWEDBERG, Richard and UDDHAMMAR, Eric (eds). Sociological Endeavor. Selected Writings. Stockholm: City University Press, 1997, pp. 191-219.

ZOLLNER, Moritz, FRITSCH, Michael, WYRWICH, Michael. An Evaluation of German Active Labor Market Policies and its Entrepreneurship Promotion. Jena Economic Research Papers. Friedrich-Schiller-University Jena, 2016-022, pp. 1-55 